Invited review

\title{
Monsoon extremes and society over the past millennium on mainland Southeast Asia
}

\author{
Brendan M. Buckley ${ }^{\mathrm{a}, *}$, Roland Fletcher ${ }^{\mathrm{b}}$, Shi-Yu Simon Wang ${ }^{\mathrm{c}}$, Brian Zottoli ${ }^{\mathrm{d}}$, \\ Christophe Pottier ${ }^{\mathrm{e}}$ \\ ${ }^{a}$ Tree-Ring Laboratory, Lamont-Doherty Earth Observatory of Columbia University, 61 Route 9W, Palisades, NY 10964, USA \\ ${ }^{\mathrm{b}}$ Department of Archaeology, University of Sydney, NWS 2006, Australia \\ ${ }^{\mathrm{c}}$ Utah Climate Center, Department of Plants, Soils and Climate, Utah State University, Logan, UT, USA \\ ${ }^{\mathrm{d}}$ Ecole française d'Extrême-Orient (EFEO), Paris, France \\ ${ }^{\mathrm{e}}$ Ecole française d'Extrême-Orient (EFEO), Princess Maha Chakri Sirindhorn Anthropology Centre, 20, Boromarachachonani Road, Taling Chan, \\ Bangkok 10170, Thailand
}

\section{A R T I C L E I N F O}

\section{Article history:}

Received 21 June 2013

Received in revised form 20 April 2014

Accepted 22 April 2014

Available online

\section{Keywords:}

Monsoon

Climate

ENSO

Angkor

Cambodia

Vietnam

Tonkin

Cochinchina

Society

Chronicles

\begin{abstract}
A B S T R A C T
The early 21st century has seen vigorous scientific interest in the Asian monsoon and significant development of paleo-proxies of monsoon strength. These include the Monsoon Asian Drought Atlas - a 700-year, gridded reconstruction of hydroclimate derived from 327 tree ring records - and several long speleothem records from China and India. Similar progress has been made on the study of monsoon climate dynamics through re-analysis data products and General Circulation Model diagnostics. The story has emerged of a variable monsoon over the latter Holocene, with extended droughts and anomalously wet episodes that occasionally and profoundly influenced the course of human history. We focus on Southeast Asia where an anomalous period of unstable climate coincided with the demise of the capital of the Khmer Empire at Angkor between the 14th and the 16th centuries, and we suggest that protracted periods of drought and deluge rain events, the latter of which damaged Angkor's extensive water management systems, may have been a significant factor in the subsequent transfer of the political capital away from Angkor. The late 16th and early 17th century experienced climate instability and the collapse of the Ming Dynasty in China under a period of drought, while Tonkin experienced floods and droughts throughout the 17 th century. The 18th century was a period of great turmoil across Southeast Asia, when all of the region's polities saw great unrest and rapid realignment during one of the most extended periods of drought of the past millennium. New paleo-proxy records and the incorporation of historical documentation will improve future analyses of the interaction between climate extremes, social behavior and the collapse or disruption of regional societies, a subject of increasing concern given the uncertainties surrounding projections for future climate.
\end{abstract}

(C) 2014 Elsevier Ltd. All rights reserved.

\section{Introduction}

The Asian monsoon comprises, arguably, the Earth's largest and most important climate phenomenon, one that directly influences the livelihood of more than $60 \%$ of our planet's human population (Wang, 2006; Clift and Plumb, 2008), and sustains regions with some of the highest and most vulnerable biodiversity on Earth (Sodhi et al., 2004). The life-sustaining rains that arrive annually with the changes in seasonal circulation over Asia give way to an

\footnotetext{
* Corresponding author.

E-mail address: bmb@ldeo.columbia.edu (B.M. Buckley).
}

annual drought of varying severity across the region. Human societies have adapted to the rhythm of the annual rains that come with the monsoon, and have flourished and suffered, often in concert with anomalous departures from its mostly predictable behavior. Over the period of recorded history, anomalously strong or weak monsoon rains have bestowed misery upon the inhabitants of widely distant regions of Asia, and this continues to the present day. Several dynamical factors in the oceans and the atmosphere either influence or are correlated with this mighty system, including the El Niño - Southern Oscillation (ENSO - Kumar et al., 1999; Krishnamurthy and Goswami, 2000), the Interdecadal Pacific Oscillation (IPO - Meehl and Hu, 2006), North Atlantic sea surface temperature (Goswami et al., 2006), the Indian Ocean 
Dipole (IOD - Ashok et al., 2001), and Eurasian snowpack anomalies (Hahn and Shukla, 1976; Bamzai and Shukla, 1999).

In this paper we present a brief overview of the rapidly growing body of paleoclimate proxies for the Asian monsoon, and we highlight the past millennium to identify the periods of greatest anomalies of climate and societal turmoil. We focus on mainland Southeast Asia (a.k.a. the Indochina Peninsula), in particular on what happened in the capital of the Khmer state at Angkor in the 14th and 15th centuries (centered in present-day Cambodia), and the events of the latter half of the 18th century when all of Southeast Asia's main polities were driven from power and drought dominated the climate (Buckley et al., 2007, 2010; Cook et al., 2010; Lieberman and Buckley, 2012). We also focus on the eastern flank of the Annamite Range, in present-day Vietnam, where the kingdoms of Tonkin and Conchinchina thrived. We present evidence from the historical chronicles from Hanoi and Hue, as well as several European sources, from the 14th through the 18th centuries of anomalous climate, disease and famine, and compare these with the results of an updated version of the tree-ring derived Monsoon Asia Drought Atlas (MADA - Cook et al., 2010: http://iridl.ldeo.columbia. edu/SOURCES/.LDEO/.TRL/.MADA/.pdsi/). We then analyze the dynamical features that lead to such anomalies over the modern period of instrumentation, and seek to identify how, and the ways in which societies dealt with their circumstances.

\section{The Asian monsoon system}

\subsection{Background}

The Asian monsoon is, at its most fundamental level, an annually occurring, hemispheric-scale wind reversal that is caused by the differential heating between the Eurasian continent and its adjacent oceans between summer and winter (Wang, 2006; Neelin, 2007; Clift and Plumb, 2008). The Inter-Tropical Convergence Zone (ITCZ) pools moisture-laden air from both hemispheres and creates strong, convective lifting that arises from heating of the surface, thereby transferring heat and moisture from the tropical oceans into the subtropics. Within the ITCZ the atmospheric moisture over the ocean ascends until it reaches the upper atmosphere where it cools, releases much of its moisture as rain, and then diverges before descending into the northern and southern subtropics, forming the classic Hadley Cell circulation. Over land, the position and expansion of the ITCZ are inter-related with the Monsoon's strength (Fleitmann et al., 2007; Yancheva et al., 2007; Sachs et al., 2009). Altering the mean location of the ITCZ therefore changes the regional hydroclimate, and has significant consequences for those who depend upon the reliability and predictability of the monsoon rains. This is particularly significant over South and Southeast Asia.

\subsection{Components of the Asian monsoon}

The Asian monsoon can be conceptualized as encompassing several related components that are not explicitly correlated. It is the boreal summer's Indian Summer Monsoon (ISM), for example, that is commonly referred to when describing the Asian Summer Monsoon, but the East Asian Summer Monsoon (EASM) and the Western North Pacific Summer Monsoon (WNPSM) have been shown as separate monsoon subsystems. The boundaries of ISM, EASM and WNPSM are outlined in Fig. 1. Importantly the Indochina Peninsula, a main focus of this paper, is sandwiched between these three regional monsoon systems, highlighting its complex climate dynamics in the context of rainfall distribution and intensity (Chen and Yoon, 2000).

In summer, moisture from the ISM is carried across the Indian subcontinent and the two adjacent seas - i.e., the Arabian Sea to the west and the Bay of Bengal to the east. The monsoonal westerly flows then split. One branch curves northward into Myanmar and Bhutan and forms a heavy precipitation belt on the windward slopes and a 'rain shadow' with contrasting semi-arid climate on the leeward slopes. A second branch crosses the Indochina Peninsula into the South China Sea where the monsoon flows turn northeastward, towards East Asia. There, the monsoon flows meet the mid-latitude westerly wind and storm track, which is still active during early summer, creating a thermodynamically unstable zone or rain band, known locally as the Meiyu in Chinese, Baiu in Japanese, and Jangma in Korean for "plum rain". The meteorological community generally refers to this rain band as the EASM (e.g., Ding, 2004; Chen et al., 2004a; Hoskins and Wang, 2006), and significant fluctuations in its intensity and/or position can bring epic droughts and floods to this highly populated region.

During the warm season, the WNPSM is integrated into the western portion of the North Pacific anticyclonic gyre - a gigantic subtropical high-pressure system that is formed by the descending branch of the Hadley circulation. Its interaction with the ISM forms a broad region of convergence due to the two opposite-direction flows - i.e., the westerly monsoon flow and the easterly Trade Winds that meet around the Philippine Sea. This convergence zone pumps moisture into the atmosphere, generating large volumes of rainfall and releasing latent heat. Its position and intensity also change year-to-year depending on the strength of the subtropical high-pressure system and/or the ISM. Long-term changes of these monsoon systems can, and have, had great societal and ecosystems impacts.

\section{Significant monsoon variability of the past millennium}

The Asian monsoon as we describe it above is thought to have developed about 10 million years ago, long before the first humans appear in the geo-archaeological record (Molnar, 2005). By the early Holocene the summer monsoon was more intense than today, and has steadily diminished in strength throughout the past several millennia in accordance with changes in solar insolation (Kutzbach, 1981; Wang et al., 2005; Maher, 2008). Rapid development in the field of paleoclimatology over the past few decades has uncovered several reliable proxies of Asian monsoon strength from a variety of archival sources - deep-sea cores, Himalayan-Tibetan ice cores, loess deposits, cave speleothems, peat bogs and, more recently, tree ring records. Fig. 2 plots a selection of high-resolution monsoon proxies that span the past millennia and these are used throughout the remainder of this paper.

Some of the strongest evidence for Asian monsoon variability over the most recent millennia comes from speleothem records from China and India (Fig. 2), two regions with the highest population density and, hence, the greatest vulnerability to variations in the strength of the monsoon (site locations plotted in Fig. 3). Sinha et al. (2010) show that the speleothem record from Dandak Cave, located in the core monsoon region of India, agrees well with the Wanxiang Cave record from China of Zhang et al. (2008), and with the Vietnam tree ring record of Buckley et al. (2010). The agreement among these paleoclimate records is particularly remarkable during the 14th and 15th centuries, one of the most tumultuous times in pre-modern Southeast Asia as well as China and northern Eurasia (e.g., Kahan, 1985; Lieberman, 2003). It was at this time that the Khmer Empire fell into disarray and its capital was abandoned, as we discuss later in this paper. It was an equally tumultuous time in China, as Zhang et al. (2008) note, when drought contributed to the demise of the ethnic-Mongolian Yuan Dynasty in 1368, and in present-day Vietnam where the kingdom of Tonkin dealt with epic drought and famine. 


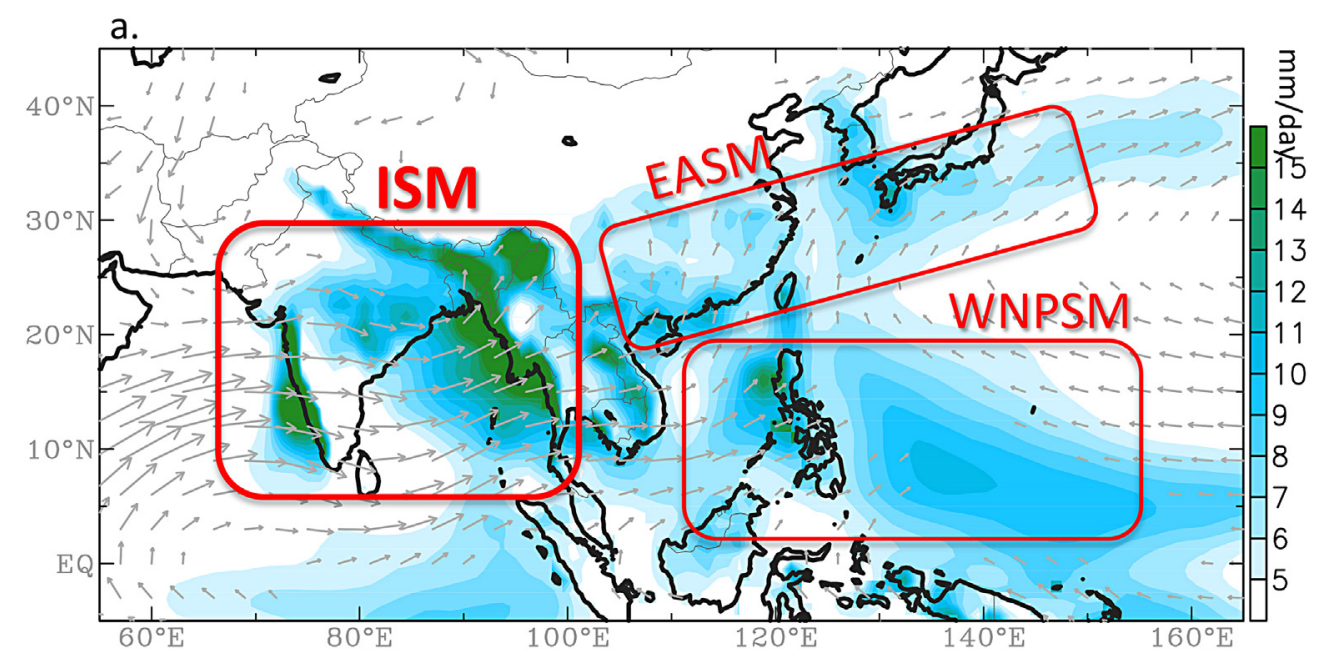

b.

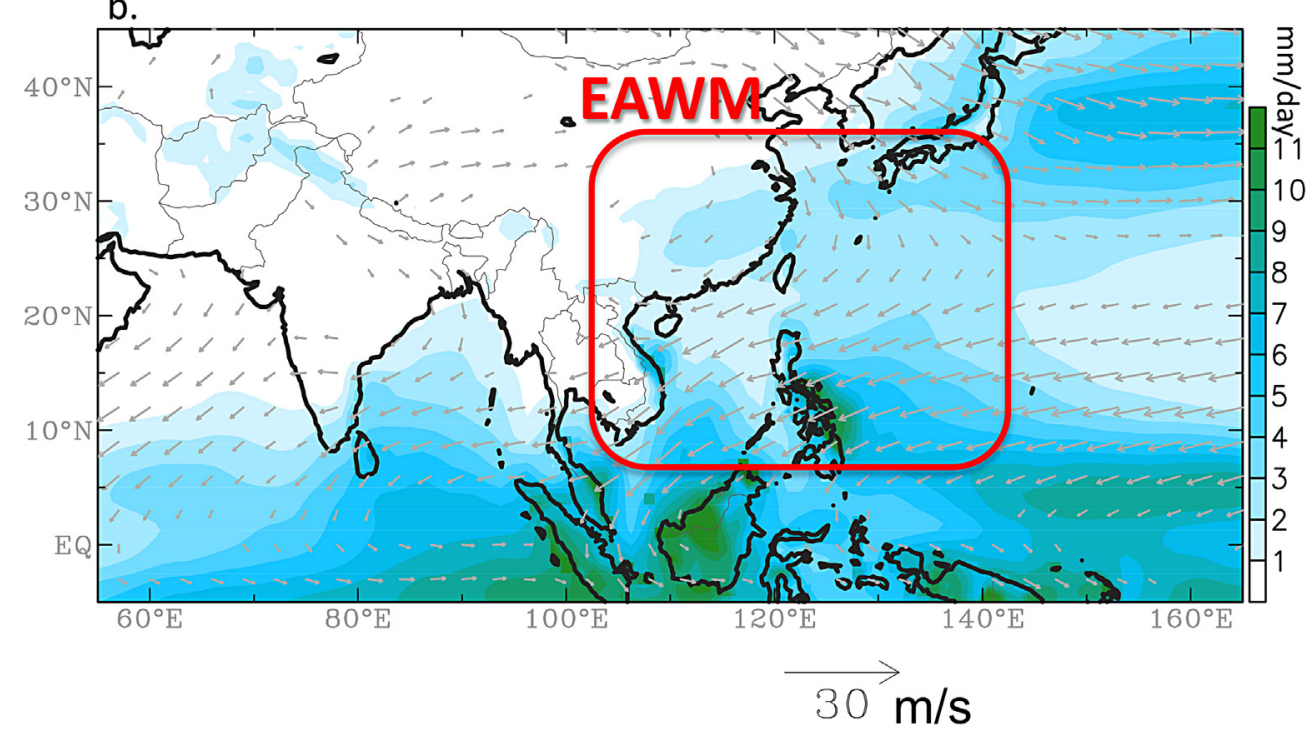

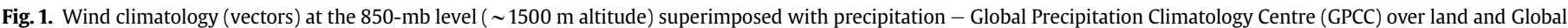

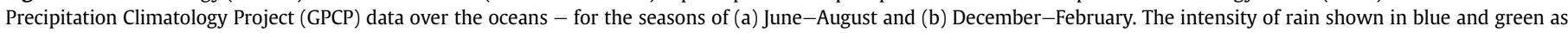

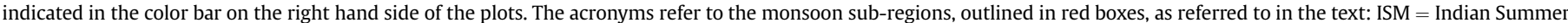

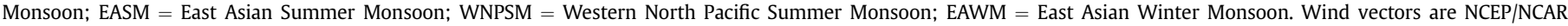
reanalysis, shadings are from Global Precipitation Climatology Center (GPCC) over land and Global Precipitation Climatology Project (GPCP) over the oceans.

Fig. 4 shows maps of the regional expression of several of the main droughts discussed in this paper, as well as the grid spacing and geographical extent of the Monsoon Asian Drought Atlas (MADA) drought indices produced by Cook et al. (2010) that are used throughout this paper. The MADA data as expressed in Fig. 4a and $\mathrm{b}$ delineate the two primary periods of drought that occurred during the late 14th and the early 15th centuries (discussed in detail in Section 4) and referred to as Angkor Droughts I and II, respectively. This period of anomalous climate was also described in the chronicles of Hanoi and Hue (see Section 5), and was noted in texts from Lanna (present-day north Thailand) that described monks from Chiang Mai being forced to return from Sri Lanka due to the severity of the drought there (Thera, 1967; Wyatt and Wichienkeeo, 1998).

The 16th-17th centuries, according to the MADA, experienced some of the most highly variable periods of both dry and wet. In China the Ming Dynasty ended during the drought of 1638-41, shown in Fig. 4 c. However it was the latter half of the 18th century when decades-long droughts wracked South and Southeast Asia that we see some of the greatest societal turmoil in the face of monsoon extremes. The "Strange Parallels Drought", so named by Cook et al. (2010) after Victor Lieberman's (2003) book by that name, spanned from India to Vietnam (Fig. 4 d) for more than a decade from 1756 to 1768, and corresponded to a period when all of Southeast Asia's main polities dissolved (Lieberman, 2003). The Bengali Famine drought of 1769-1773 (Fig. 4 e) and the East Indian Drought of 1790-1796 (Fig. 4 f), each resulted in millions of deaths due to starvation, marking the 18th century as one of the most tumultuous of the past millennium, when successive decades of weakened monsoons took their toll.

The two most significant events of the recent past are the Victorian Holocaust Droughts of the late 19th century, triggered by the El Niño events of 1877-79 and 1888-90, respectively (Davis, 2001), shown in Fig. $4 \mathrm{~g}$ and h. These two events were responsible for millions of deaths globally, and hit South Asia particularly hard. The first Victorian Drought had a near-global impact, but was particularly severe across a wide swath of Asia, with famine and deaths in India and northern China (Davis, 2001). These historical 


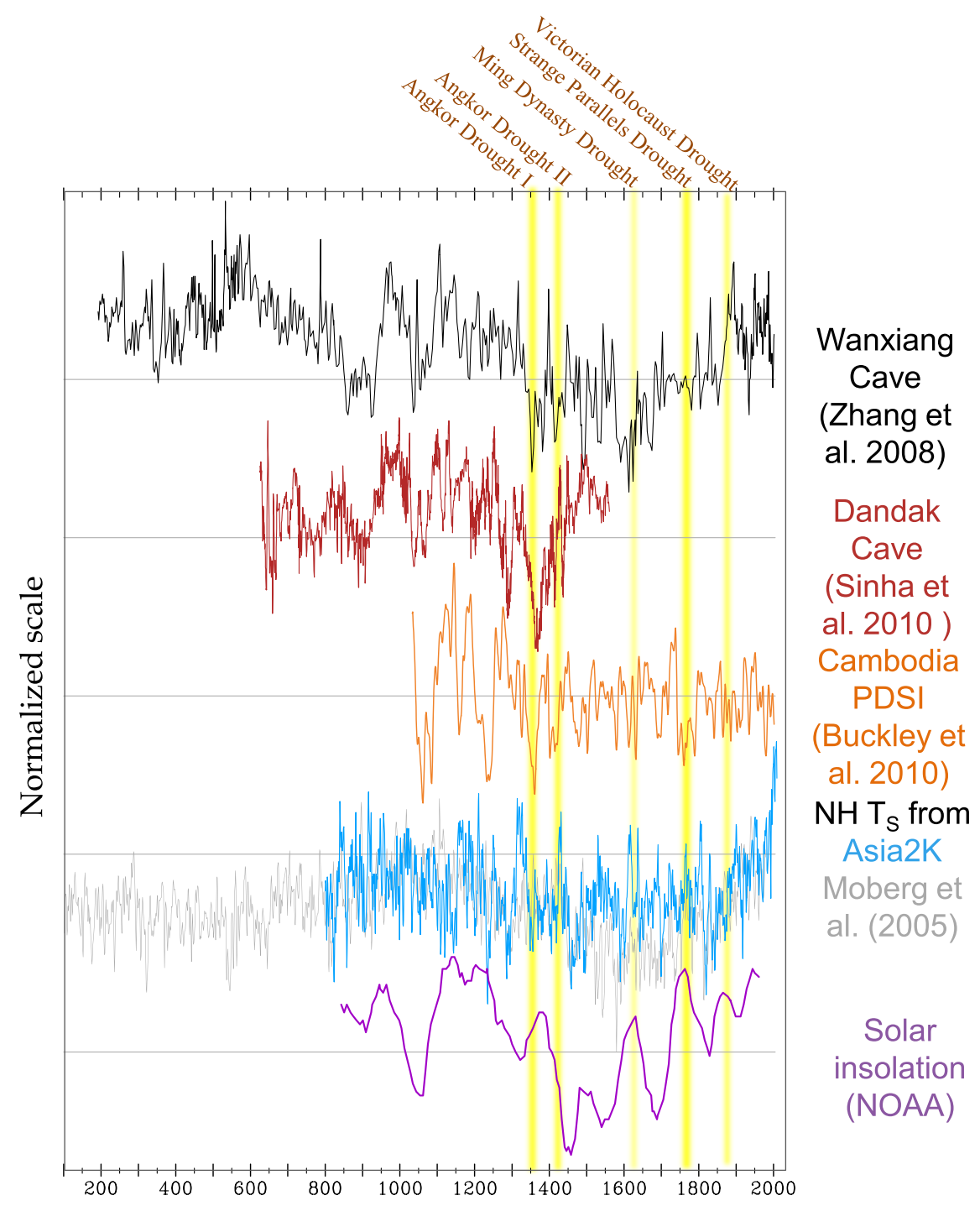

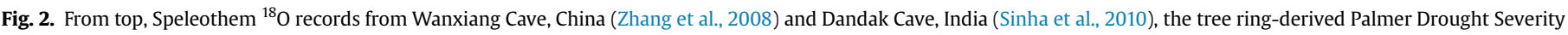

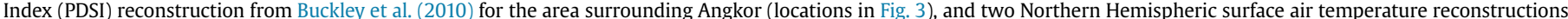

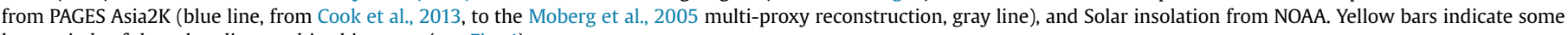
key periods of droughts discussed in this paper (see Fig. 4).

accounts of drought and associated famine are faithfully recorded by the MADA data, and give insight as to the general causes of monsoon failure for this region, as discussed later in this paper.

\section{Monsoon variability and societal behavior in mainland Southeast Asia}

\subsection{The Khmer capital at Angkor}

The Khmer capital at Angkor, in present day Cambodia, was founded around $900 \mathrm{AD}$ and by $1400 \mathrm{AD}$ had declined significantly. At the peak of its extent in the 12th and 13th centuries Angkor was a low-density mega-city with a population of approximately 750,000 spread over an area about $1000 \mathrm{~km}^{2}$ (Fig. 5). Most of Ankgor's major public works (i.e., temples and water infrastructure such as the baray, or reservoirs) were built during the 12th and 13th centuries, with the last baray having been built in the late 12th century. During the late 13th century Angkor was thriving, according to the Chinese envoy Zhuo Daguan who penned the only known account of life at Angkor from a visit in 1295-6 (Harris,
2007). Between the late 13th and the late 16th century, however, Angkor declined to a kernel of its former self (Coe, 2003; Fletcher et al., 2003; Evans et al., 2007). Few surviving primary texts exist in Cambodia, with the last inscription in Sanskrit dated to around $1330 \mathrm{AD}$, and no inscriptions from 1328 to 1546 . Angkor Thom was briefly used between the 1540s and 80s (Groslier, 2006), but by the late 16th century Angkor had experienced a profound urban decline, and the seat of state power moved to the region around present day Phnom Penh (Coedès, 1913). Fig. 6 illustrates a time line of some major historical events overlaid with the Buckley et al. (2010) PDSI record for reference.

Given such large numbers of people in the urban complex of Greater Angkor, one should not suppose that the exodus of the elite was coordinated with the dispersal of the majority of its population. No primary historical records tell us when the elite left, although historically problematic secondary sources (sensu Vickery, 1977) ascribe it to the 1430s when Ayutthaya temporarily took control of Angkor (Groslier, 2006). Nor do any texts describe the manner in which, or when, the general populace moved away. They did not die abruptly, or at least no skeletal remains have yet been 


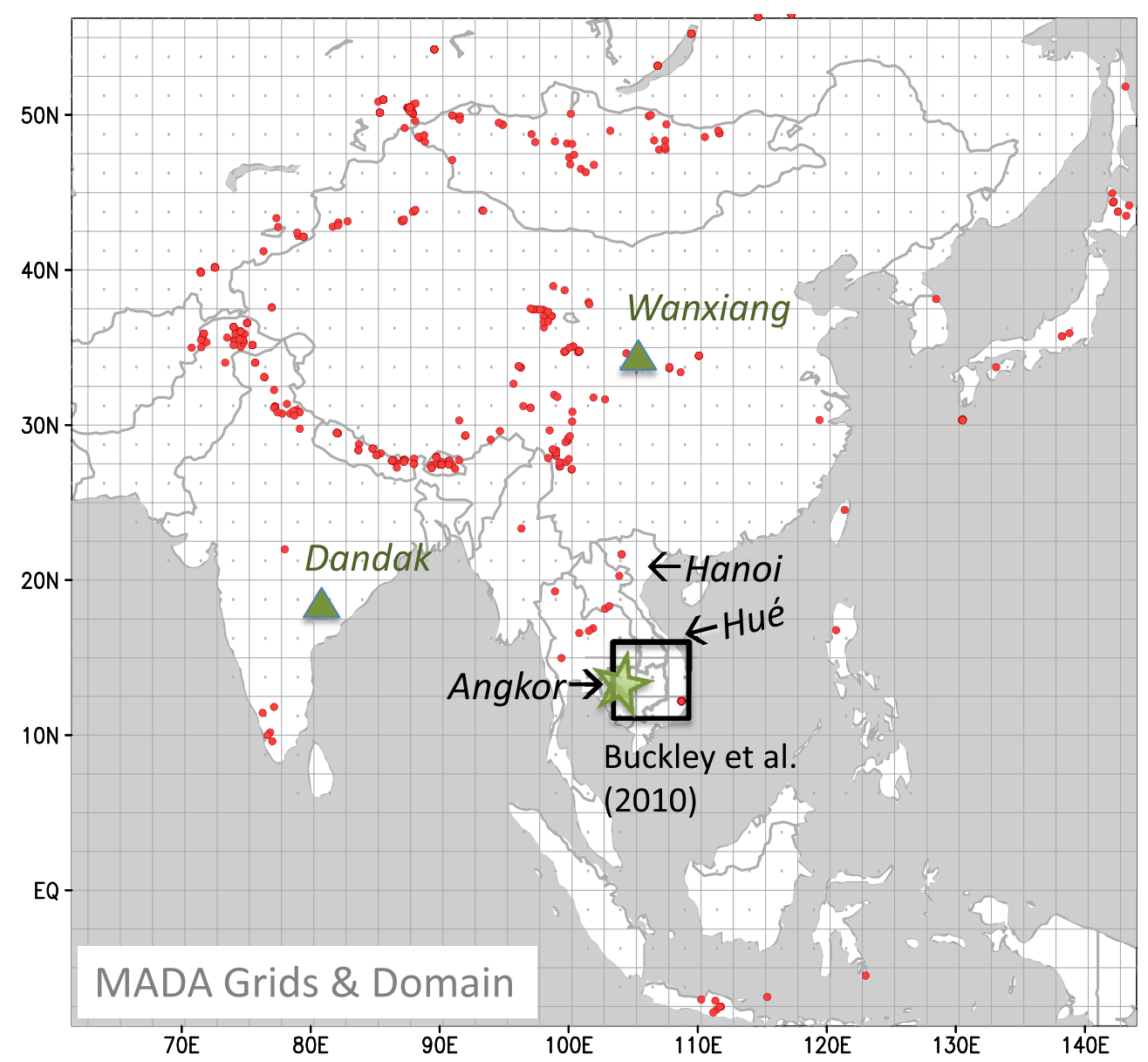

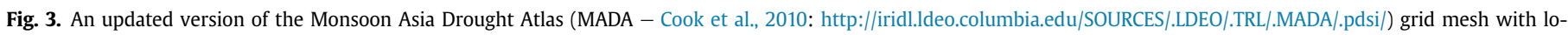
cations of its underlying tree-ring.

found that might indicate a demographic disaster such as epidemic disease or a military catastrophe, though epidemics are known in the region at this time. Wongthes (2009) describes disease as the reason for the Siamese move from La Wo (present day Lop Buri) to its new location at Ayutthaya because of an outbreak of disease in 1350 , but it is not clear what disease this was. The Tonkin dynastic chronicle described in Section 5.1 also describes epidemics in what is now northern Vietnam, in 1407 and 1409.

\subsection{New evidence from LiDAR at Angkor}

The recent Khmer Archaeology LiDAR Consortium (KALC) survey offers much new and revealing information about selected parts of the structure of Angkor. By the 12th century much of the Angkor plain and the low lying slope below the Kulen-Khror hills (see Fig. 5) had been converted to bunded rice fields (Fletcher et al., 2008; Hawken, 2011). By the 14th century the landscape of the entire Angkor region had been profoundly altered by centuries of forest clearance to extend rice production, especially in the lowlands. Where there once was continuous forest canopy there were now patches and strips of anthropogenic woodlands clustered around the houses on their raised mounds, and along the embankments of the roads and the water network. The KALC survey has revealed rice fields under today's dense tree cover of the area about $90 \mathrm{~km}$ north of the Kulen Hills at Koh Ker (Fig. 7). Heng (2002) argued that much of central Cambodia between the Dangrek Mountains and the hills north of the Tonle Sap had been cleared for farming, resulting in the sparse tree cover and minimal soils that persist to the present day. High magnitude rainfall events might therefore have caused flooding and erosion, and damage to the embankments and channels of Angkor's water network.

Sand deposits that fill the old Siem Reap canal (see section 4.5) derive from the same processes that affected the floodplain near the Kulen Hills, where the Siem Reap River is deeply incised up to $8 \mathrm{~m}$ below the surrounding land surface. From the Bam Penh Reach offtake southwards to the vicinity of Angkor Wat, the current river is now 5-8 $\mathrm{m}$ lower than the Angkorian ground surface. At the western end of the gap between the Jayatataka and the East Baray (or reservoir, as shown in Fig. 8) is a north-south dam (a) that the LiDAR shows was breached at a high level by rapidly moving water that gouged into the side of the south bank of the Jayatataka (b), before turning southwards through the gap (c) in the eastern end of the North Cross-Embankment/Wall. To the south the erosion channels tore away the northern edge of the residential area adjacent to Ta Nei (d) and flowed to the southwest at a high level through the housing (e), causing severe damage before flowing back into the main Siem Reap canal. Subsequently the Siem Reap canal cut down to its present level, followed by severe erosion of the channels to the west that cut away the northern part of the housing on that side as well. About one kilometer to the south water also cut a channel around the eastern end of the Spean Thma Bridge, bypassing the old canal that flowed through it at a high level and ruining the bridge. Once this downcutting began, all of the inlet and outlet connections between Angkor's water network and the 

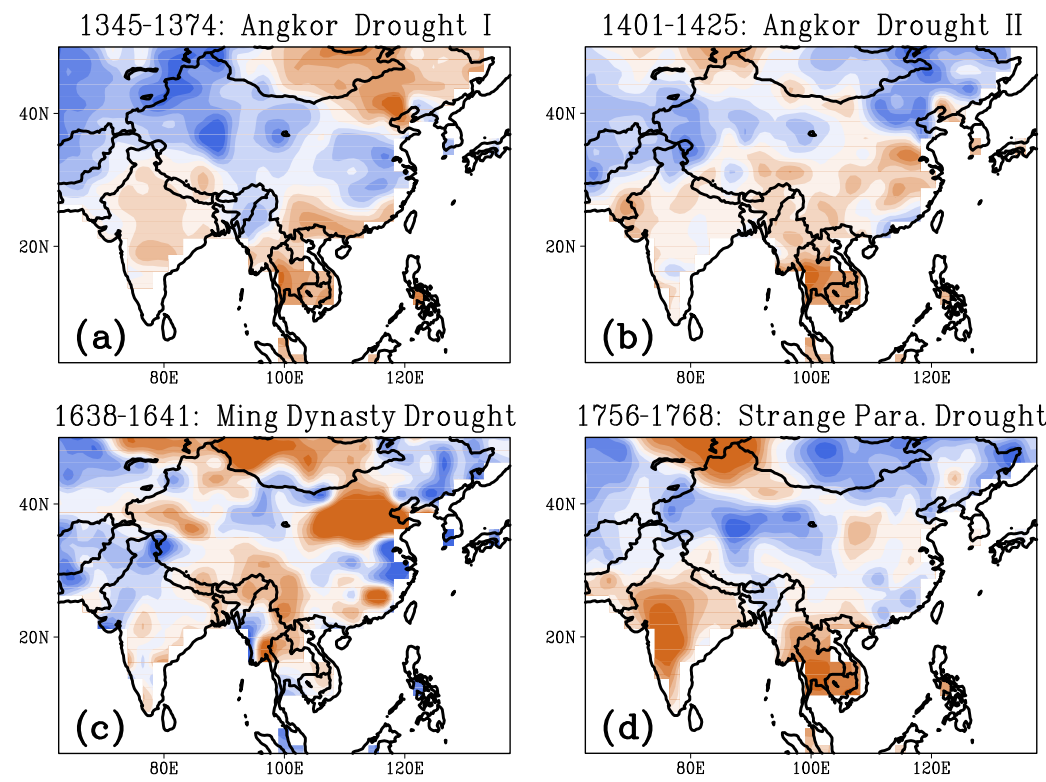

1756-1768: Strange Para. Drought

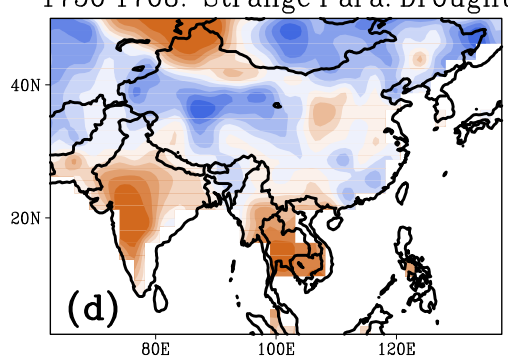

1

0.8

0.6

0.4

0.2
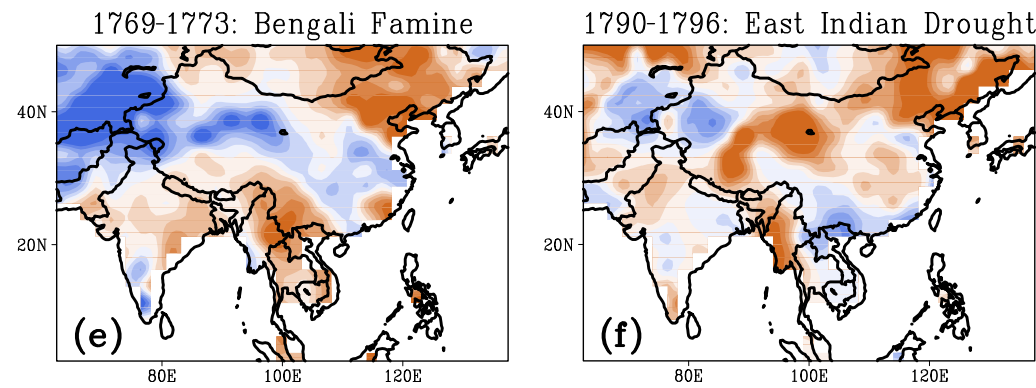

0

$-0.2$

$-0.4$

$-0.6$

$-0.8$

$-1$
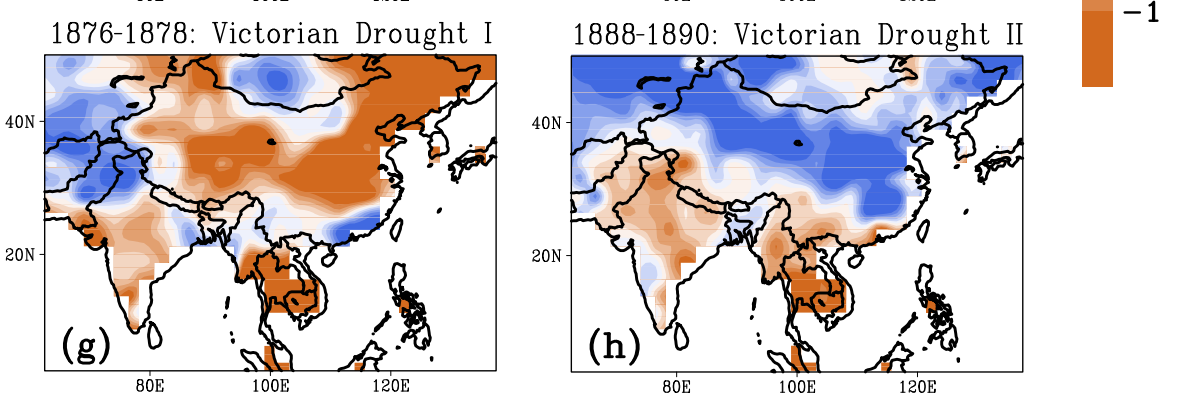

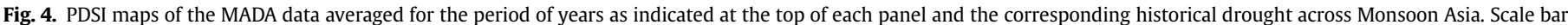

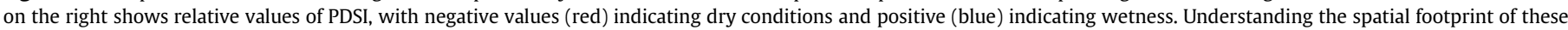

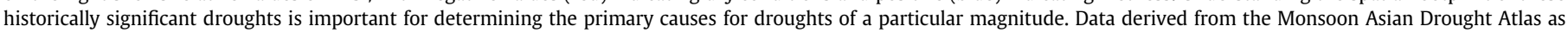

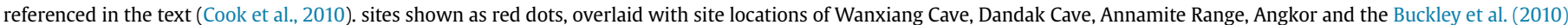

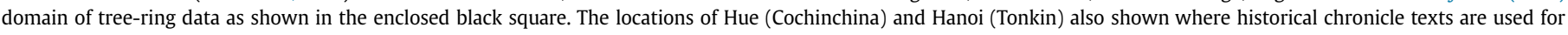
climate information as shown in Fig. 12.

old canal were severed, and water could no longer be moved between the eastern and the western portions of the network (Fig. 9). The only explanation for such substantial damage in these waterways is abnormally high, intense amounts of rainfall.

\subsection{The role of climate in Angkor's demise}

Between 2004 and 2009 field research led by the University of Sydney's Greater Angkor Project (http://acl.arts.usyd.edu.au/ angkor/gap/) revealed apparently contradictory information about water damage to Angkor's water-management network - an admirable system constructed during the Medieval Warm Period's (MWP) friendlier climate from approximately the mid 10th to mid 13th centuries (e.g., Lamb, 1965). Importantly, sometime between the 12 th and the 15 th centuries there were significant alterations to the baray that were designed to mitigate water shortages and drought. At the same time vast amounts of sand washed into the canals as the result of water overload. The tree ring-derived climate data constructed by Buckley et al. (2010) helped explain these phenomena by revealing alternating strong and weak monsoons during the 14th and 15th centuries that coincided with the timing of Angkor's demise (see Fig. 6). Droughts were also inferred by Day et al. (2012) for this same period from sediment cores taken from the $8 \times 2 \mathrm{~km}$ West Baray. These core samples also revealed an increase in sand deposited the early 15th century, suggestive of wet conditions between the periods of drought and consistent with the Buckley et al. (2010) record. Sinha et al. (2010) noted weak monsoons over India from their Dandak Cave speleothem record, as did 


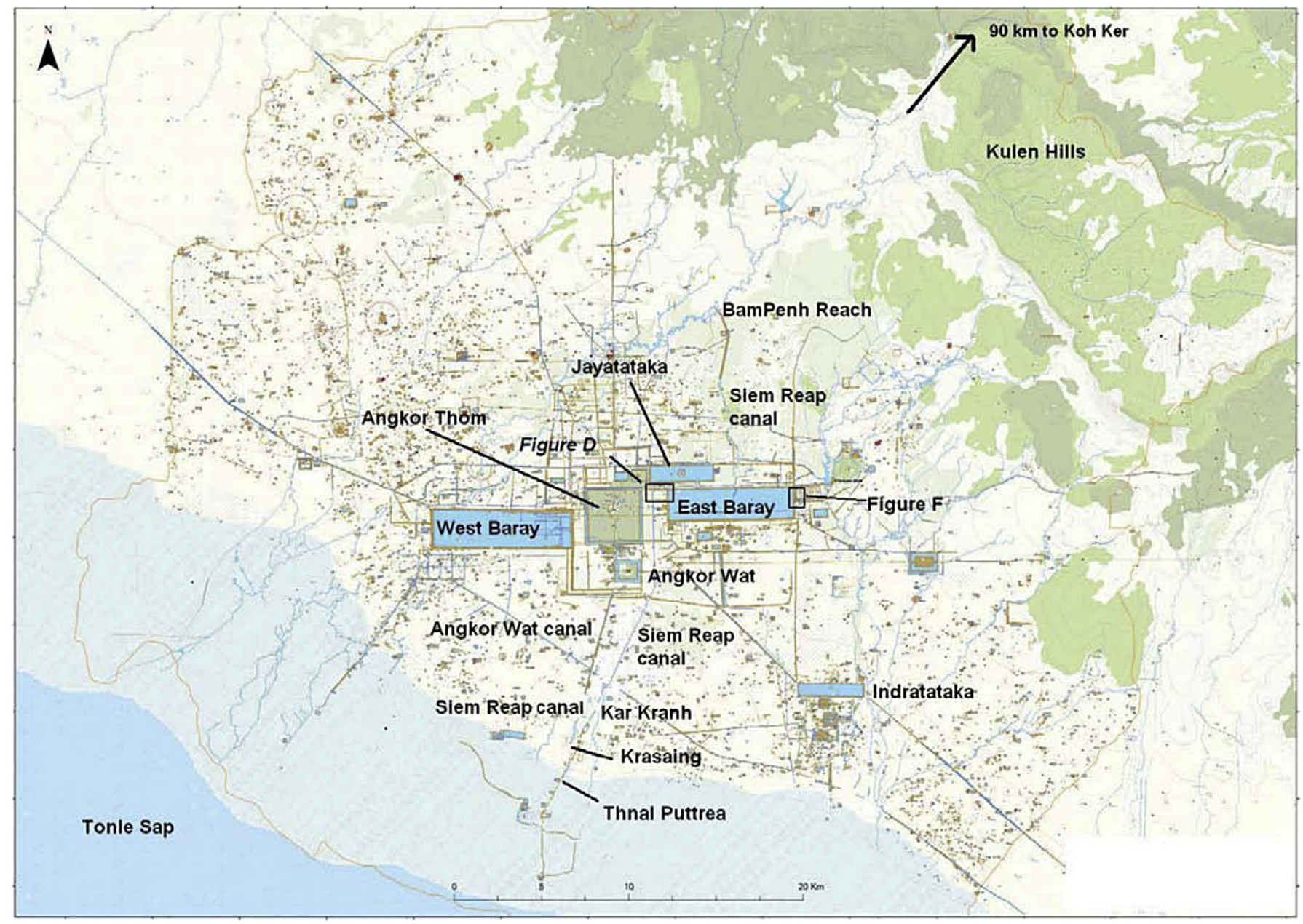

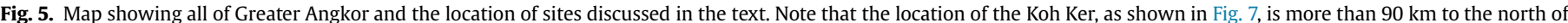

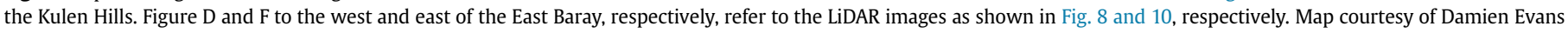
and Christophe Pottier.

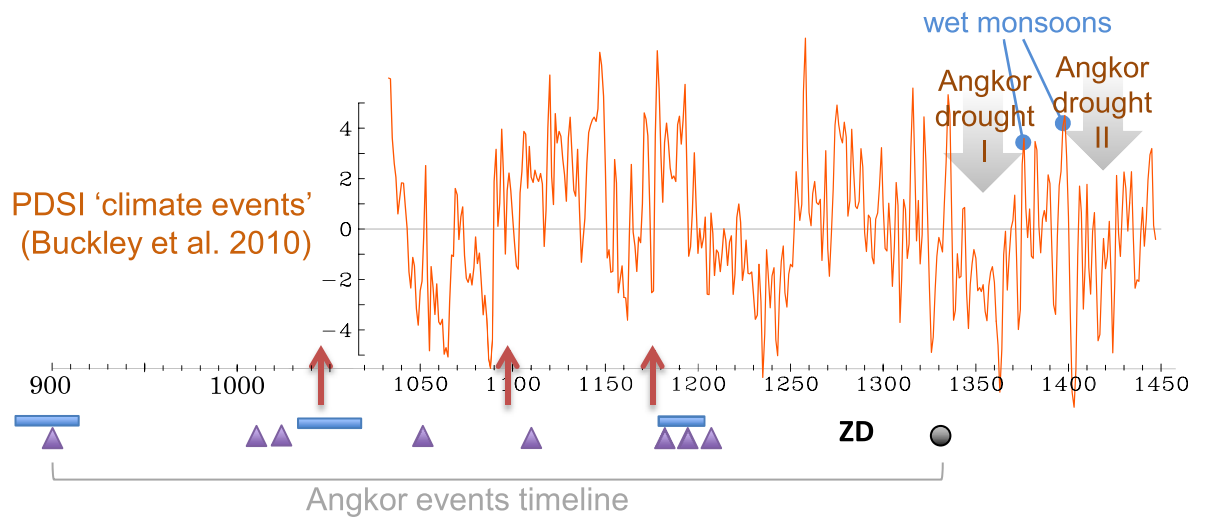

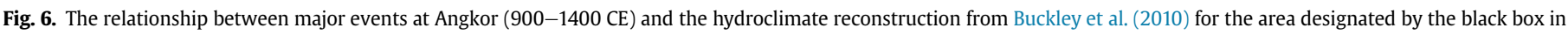

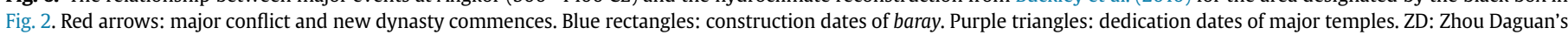

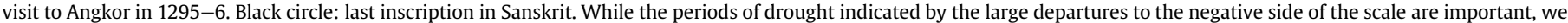

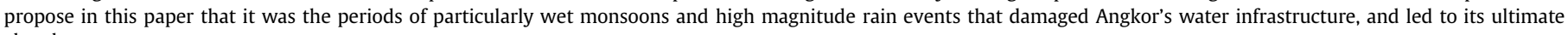
abandonment.

Zhang et al. (2008) from Wanxiang Cave in China (Fig. 3). Both records match the same periods of drought as the Buckley et al. (2010) record, which also revealed extreme wet years within the period of general wetness that is sandwiched between the two protracted Angkor droughts (Fig. 6). The LiDAR results implicate epic floods as the cause of Angkor's infrastructural damage sustained between the late 13th and the late 15th centuries, consistent with the proxy records noted in Fig. 2. While Angkor appeared to 


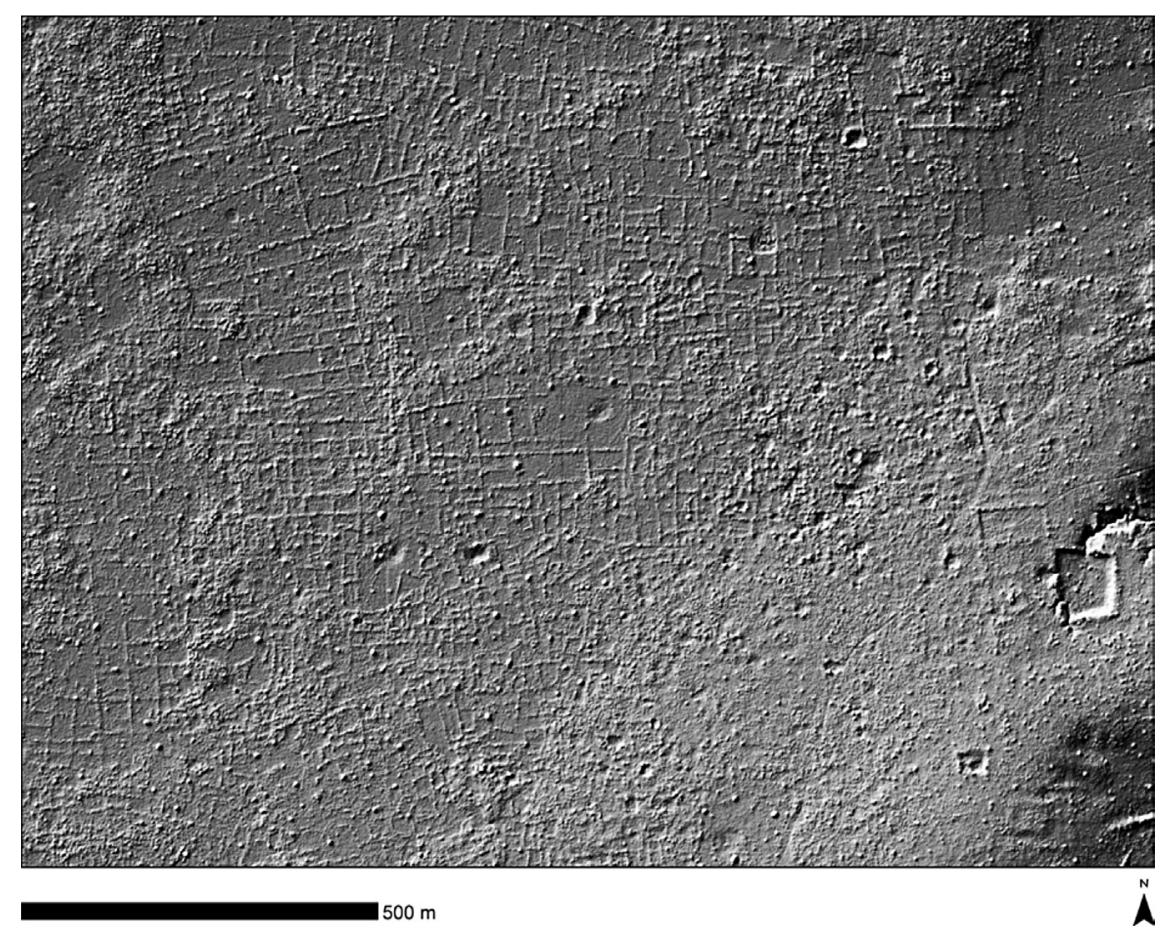

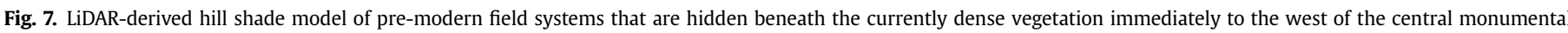

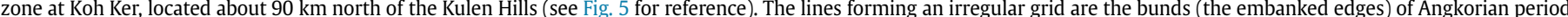

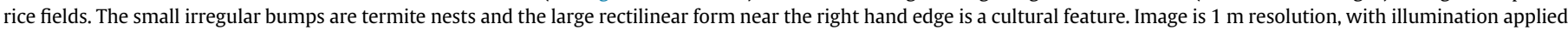
from $45^{\circ}$ altitude with a $315^{\circ}$ azimuth (Image courtesy of the Khmer Archaeology LiDAR Consortium).

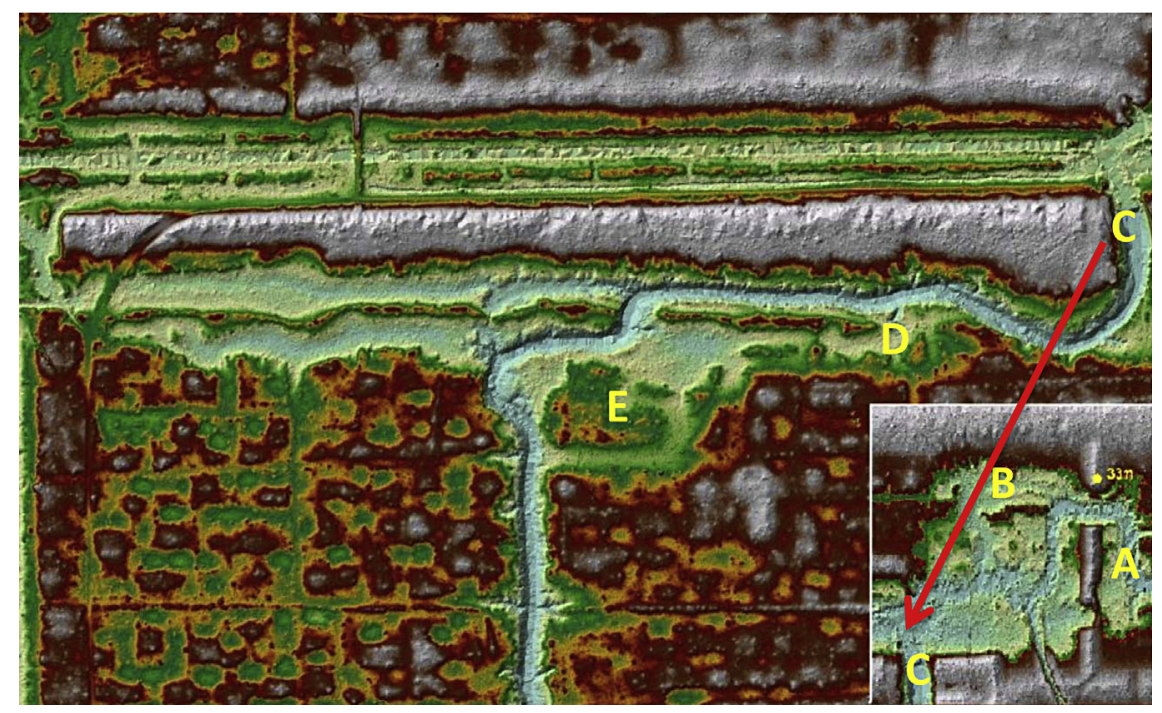

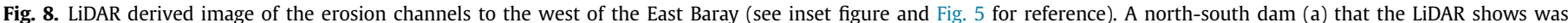

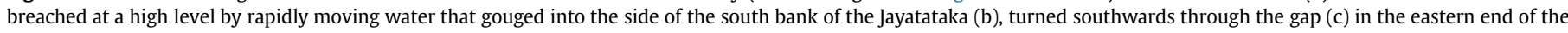

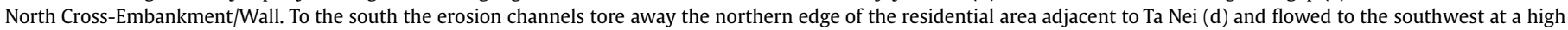
level through the housing (e), causing severe damage before flowing back into the main Siem Reap canal. (Image courtesy of the Khmer Archaeology LiDAR Consortium).

have experienced episodic droughts between 1050 and 1100, the West Baray had just been built and was fully operational, and therefore provided a massive risk management mechanism to deal with the effects of drought. However, the prolonged drought during 1200-1250 may be implicated in the attempted reconfiguration of the baray (see below 4.5), and when a series of 14th century mega monsoons damaged the old infrastructure the city no longer had a shield against drought and had no rivers large enough to fall back on.

\subsection{An abundance of stressors}

The persistence of Angkor as an economically viable, gigantic urban complex would have been quite improbable after the 15th century. While the regional climate became unstable at the end of the MWP, the social and political landscape was also transforming. By the end of the 14th century the southward movements of the Thai and Vietnamese exerted pressure on the eastern and western flanks of the Khmer state, respectively. From the 13th century 


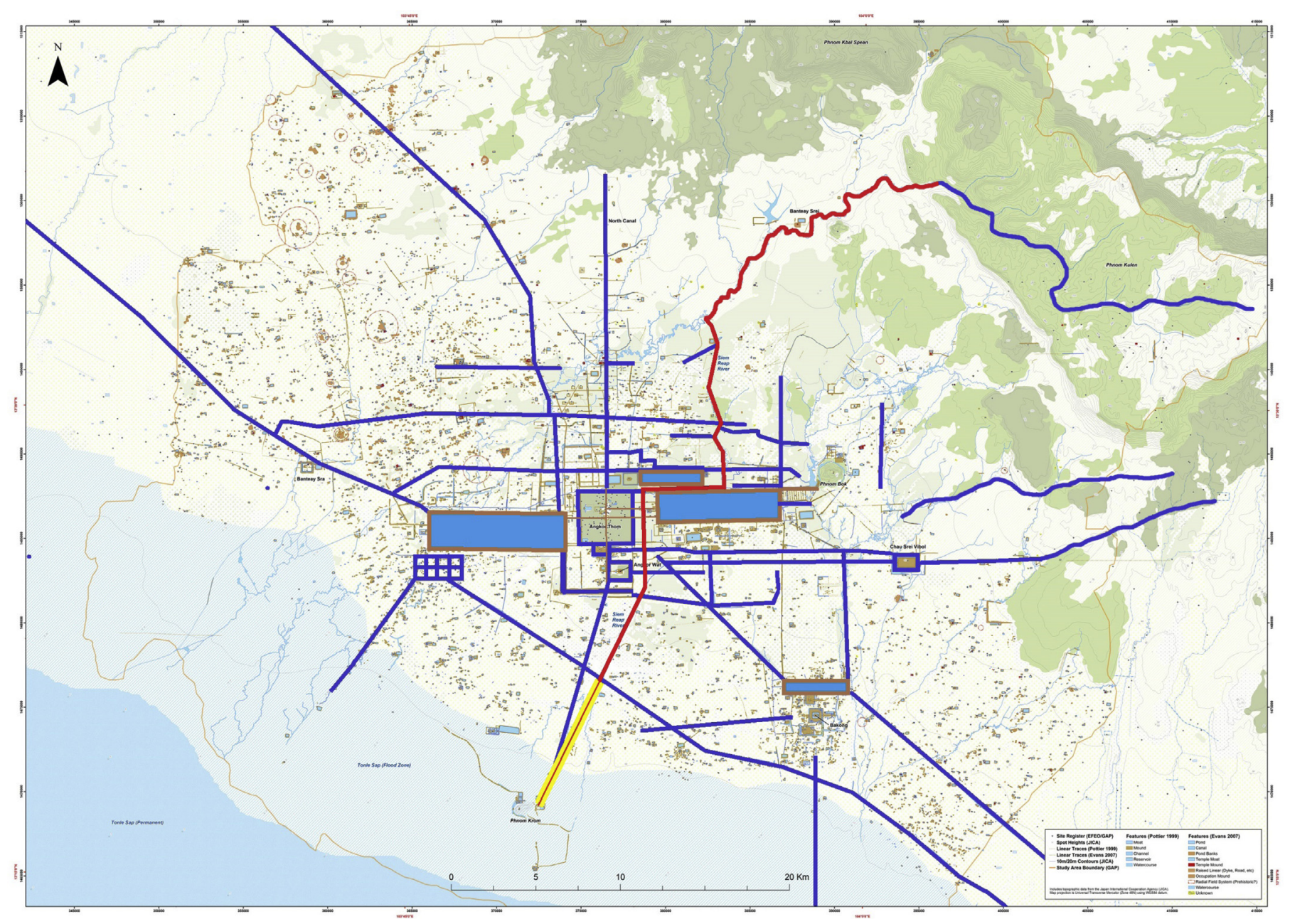

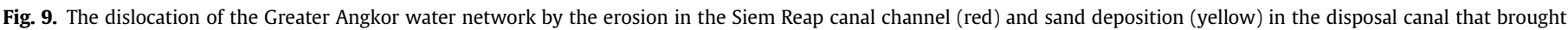

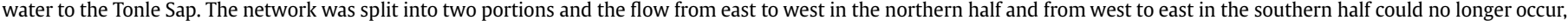
permanently altering the functioning of Angkor's massive hydro-infrastructure. Data used for this image courtesy of the Khmer Archaeology LiDAR Consortium.

onwards Theravada Buddhism began moving into the Khmer world from the west (Harris, 2008), and altered the political and social relationship between the elite, the great shrines, taxation and the general populace (Dagens, 2003). By the 16th century the maritime world had begun to transform the economies of Southeast Asia, as the wealth that could be gained from Arab, Indian, Southeast Asian and Chinese ship-borne trade began to supersede the old wealth of stable rice production in interior river basins. European traders began to enter this interconnected and competing mercantile system as they circumvented the core Arab states from the 15th century onwards. Lombard (1970) and Vickery (2004b), among others, have argued that "globalization" of commerce in East and Southeast Asia from the early 15th century played a role in undermining the Khmer empire. We contend that anomalous climate variability exemplified by periods of extreme aridity and wetness that exceeded the populace's normal experience, had serious material consequences, and added an additional burden that may have proved too much to bear.

\subsection{Evidence of deterioration of baray and canals}

All of Angkor's extant baray originally had eastern exit channels, but these were all either buried or blocked sometime subsequent to the late 12th century, with the exception of the blocking of the Indratataka exit, the date of which is unknown.
The West Baray exit was buried by the construction of Angkor Thom and the Jayatataka exit must have been blocked when the outer enclosure of Ta Som was built in the late 12th or early 13th century outside the east bank of the baray. The 9th century East Baray exit (Fig. 10), the huge masonry-lined Krol Romeas channel, is still visible but was blocked by a masonry wall of 12 th-13th century or later style (see Sonnemann, 2011 for GPR survey). Eventually it was converted to an inlet channel fed by a canal that was dug down the outer, eastern side of the northern half of the east bank of the baray. The East Baray, like the others, had been converted into a holding tank for water with no function for dispersing water through the old massive eastern channels - a reflection of the relatively stable climate under which it was designed. There may have been some dispersal through gaps in the southern banks of the baray, but these breaches cannot as yet be dated. A relatively new canal was built for the East Baray but it brings water from the same point as the old exit channel, indicating that what had changed was not the source but the available quantity of water which at this point was only enough to fill the baray halfway. The West Baray had been displaying deterioration and lack of water since the 13th century (Penny et al., 2007), indicating that water shortages had worsened over the 13th and 14th centuries, and the baray were never returned to their former role as a system to shunt packages of water out into the southern canals. 


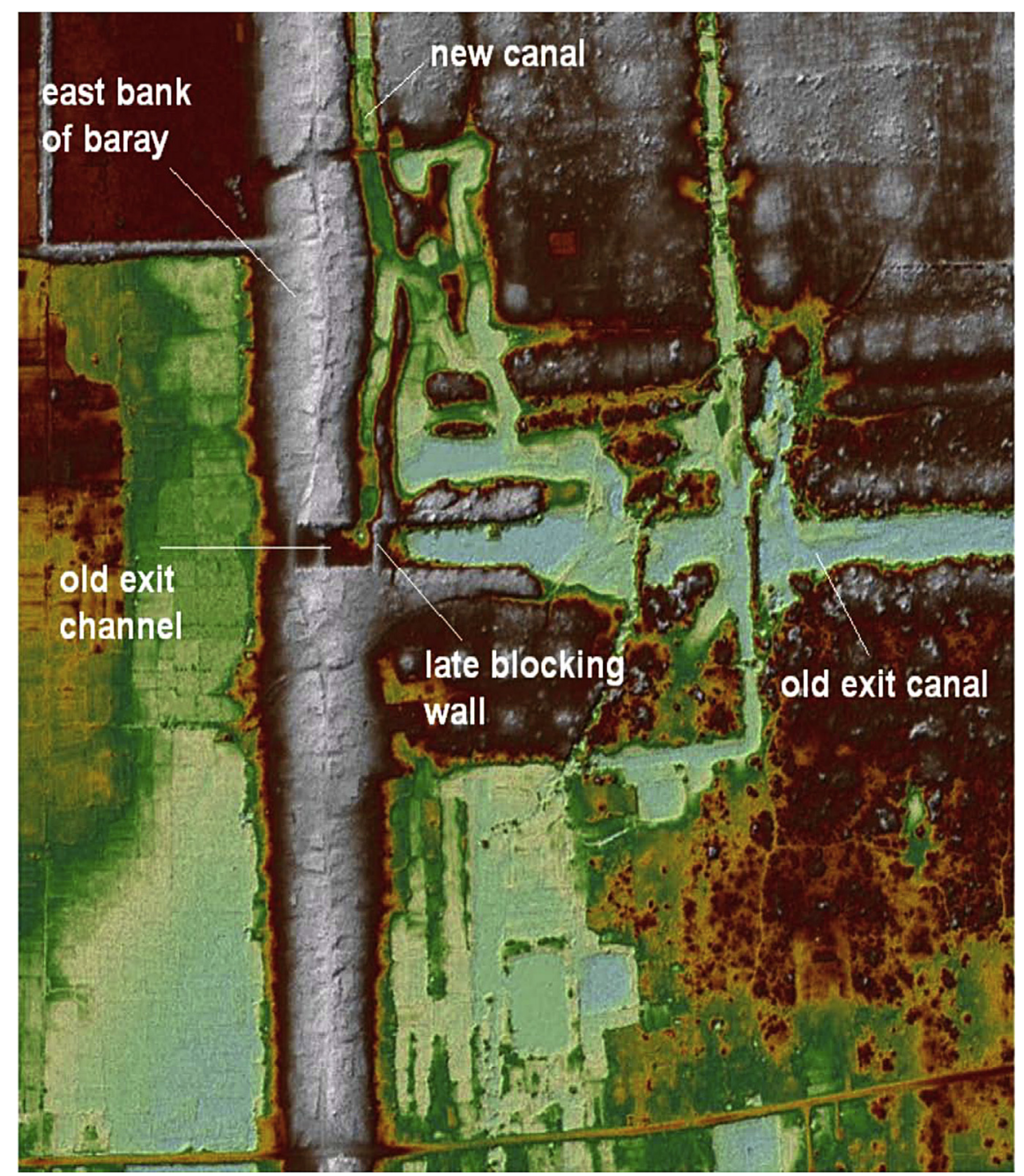

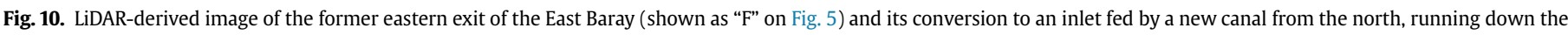
outside of the eastern bank of the baray (Image courtesy of the Khmer Archaeology LiDAR Consortium).

In contrast to the water shortages indicated by the baray modifications, the big southern canals that run directly to the Tonle Sap are filled with cross-bedded sand of medium to coarse grain size the result of large quantities of rapidly moving water that abruptly slowed as it reached the floodplain south of central Angkor. Sand also fills the channel of the western disposal canal from the West Baray, the Angkor Wat canal near the junction with the SE Canal (Sam Player, pers. Comm.), and further south to the west of Kar Kranh. In the former Siem Reap canal at Kar Kranh and at Thnal Puttrea the sand is dated to the 14th and 15 th centuries (from ${ }^{14} \mathrm{C}$ dates of vegetation preserved in the sand - Fig. 11) while just south of Wat Attvea a wooden boat, ${ }^{14} \mathrm{C}$ dated to the 14 th century, has been retrieved from a thick layer of sand in the canal. This is consistent with the severe upstream erosion that can be seen both on the ground and with great clarity in the LiDAR images.

\subsection{Summary and conclusions about Angkor's demise}

Here we present new evidence that Angkor's complex, massive, and aging water management infrastructure was affected by extreme surpluses and deficits of water, and while the droughts had serious consequences, it was the high water events that caused significant damage to key components of Angkor's infrastructure. Once broken, the Khmer's risk management system failed and food

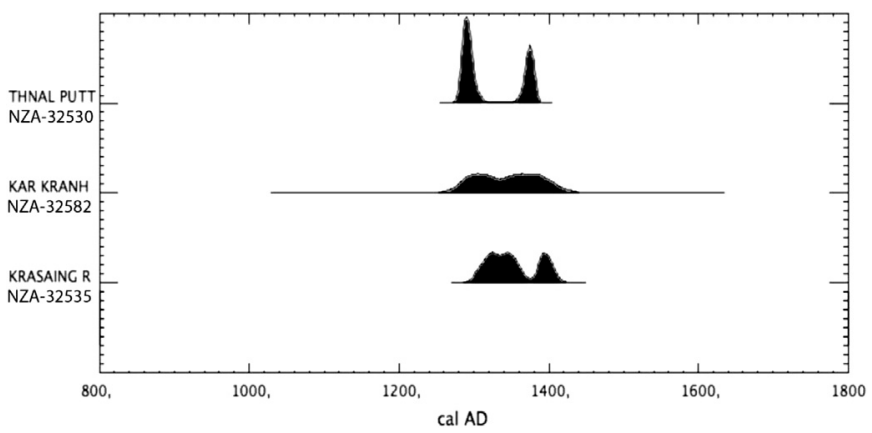

Fig. 11. Calibrated ${ }^{14} \mathrm{C}$ dates for organic material deposited in the sand in the southern canals. At Kar Kranh and Thnal Puttrea (see Fig. 5 for location reference). The organics consisted of leaves, nuts, seeds and twigs that were preserved by waterlogging and were collected during excavation by the Greater Angkor Project. At Krasaing, just south of Wat Attvea, the organics were taken from a complete wooden boat preserved by waterlogging, which was found by sand miners from ASPARA. $\left({ }^{14} \mathrm{C}\right.$ dates for the boat, courtesy of APSARA).

procurement became problematic for the urban population. With the network degraded and crop yields reduced the operational logic of the urban complex vanished. The massive scale of Angkor's infrastructure led in turn to damage on an equally huge scale and 
created problems that were either beyond repair, or deemed not worth the cost of repair. Until the water flow of the Angkor plain returned to a new equilibrium the damaged structures caused disruption, inconvenience and risk. Movement of the populace to other regions would have been simpler than trying to rectify part of the damage and then risk being overwhelmed by further erratic and unpredictable upstream failure of the old infrastructure.

The Khmer had created a more manageable and less risk-prone environment, but by the 13th century some critical components of their hydraulic infrastructure were between 300 and 500 years old, profoundly complex and full of redundancies. While the system had successfully coped with drought since at least the 9th century when the Indratakata was built, the archaeological record indicates that high-magnitude water events caused structural damage. We posit that the network and the way the water system was managed simply could not facilitate adjustments to the increasingly unpredictable impacts of extreme monsoons, and its complexity and age produced a breakdown cascade.

The Buckley et al. (2010) climate record suggests that the highly variable and unpredictable climate of the 14th and 15th centuries played a significant role in Angkor's demise (see Section 6). Angkor's rise coincided with the favorable climate of the MWP, but its demise occurred during an unstable transition to the LIA that was marked by a $5^{\circ}$ southward shift of the ITCZ (Sachs et al., 2009) that fundamentally changed the regional climate. Buckley et al. (2010) contended that it was the scale of this climatic change that was the catalyst for the demise of Angkor. Here we contend that the anomalous climate was a key factor among a plethora of changes, societal and environmental, that led to crisis from the mid 14th to late 16th century. Angkor faced change on every scale, from the vagaries of long-term, natural climate variability to the rapid decisions of communities and individuals, without the capacity to make sustainable adjustments in situ, and ultimately moved from an unusable Angkor to the Phnom Penh region at the periphery of the old state. Climate's decisive impact was the irretrievable damage caused by water excess to the infrastructure. Angkor as it had been at its apex became untenable, and the consequences ricocheted throughout the Khmer world and beyond.

\section{Historical descriptions of climate east of the Annamite Range}

\subsection{Climate information in dynastic chronicles}

Tonkin, Champa and Cochinchina were historical kingdoms in present-day Vietnam, centered on several watersheds along the coastal zone to the east of the Annamite Mountain Range. Here we present descriptions of environmental (mainly climate) conditions gleaned from regional historical chronicles and European reports, for comparison with the tree-ring derived climate reconstructions from the MADA. Reports on climate are found in the Hanoi history of the Le Dynasty (in power from 1428 to 1527 and again from 1592 to 1787), Dai Viet Su Ky Toan Thu, first produced in 1479 and with supplements describing later periods surviving in printed editions and hand-copied manuscripts (Dai Viet Su Ky Toan Thu, 1697; Ngo and Nguyen, 1991). Descriptions of climate also appear in early volumes of Dai Nam Thuc Luc, a Nguyen Dynasty (1802-1945) history of Cochinchina since the 16th century produced in Hue in 1844 (Dai Nam Thuc Luc Tien Bien, 1844). We emphasize that these texts must be read with caution, as statements about the natural world may refer to actual events or to a court's perceived political failings or instability. Chronicles may have been compiled or recompiled over several centuries and descriptions of earlier periods were potentially subject to alteration, but from the early 17 th century onward these texts can be compared with reports by foreign merchants and missionaries. Temporal control can be confirmed by calibration with the solar eclipse records, though we have found this to be occasionally problematic.

\subsection{Descriptions of climate variability from the 14th to 16th centuries}

As China and Angkor struggled with the unstable climate of the late 14th and early 15th centuries, response to these climate extremes to the east of the Annamite Mountains in Tonkin and Champa were similar in some respects, but markedly different in others. Lieberman and Buckley (2012) speculated that Tonkin was less prone to crisis than other parts of the region because it faced no Tai incursions, although the significance of Tai incursions for Angkor's demise has been reconsidered by Vickery (2004b), who noted that raids on Tonkin by Champa between 1361 and 1390 helped end the Tran Dynasty (1225-1400), and that at this time warfare, famine, disease and emigration may have halved the Tonkin population to an estimated 1.5 million. Furthermore, Chinese shipping that bypassed Northern Vietnam may have contributed to Champa's relative success.

The Hanoi chronicle describes drought in Tonkin with an unusual regularity in this period: in 1343, 1345, 1348, 1355, 1358, 1362, $1374,1379,1392-93$, with famine occurring in 1392-93 and again in 1437, consistent with the timing of Angkor Droughts I and II as shown in Fig. 4 a and b. A grain supply problem in Tonkin resulting from drought in Hu-guang in China in 1427 is also referenced in the Ming Dynasty's record (Ming Shi-lu) suggesting that drought in parts of China might have accelerated Ming troop withdrawal. No droughts are described in the Tonkin chronicle during the Ho Dynasty (1400-1407), when the capital moved south to Thanh Hoa Province, or during the Ming occupation of Tonkin (1407-1428). However, epidemic and hunger is reported in 1407 and 1409, with harvests lost to insects five times in 1393 and between 1434 and 1446 , with drought again in 1434,1437 . The Hanoi chronicle reports floods in 1333, 1336, 1338, 1351-52, 1355, 1359, 1360, 1378, 1382, 1390,1393 , and 1407, and also during the Ming occupation in 1411, 1421 and 1422. This suggests that the Angkorian dilemma of water management systems being overcome by heavy rainfall on the heels of prolonged drought was also a serious problem for the hydraulic culture of the Red River Delta. Since the agricultural land there was never abandoned, however, archaeological investigation has proven more problematic.

There are several possible factors that may have contributed to a reduced impact of alternating drought and heavy rains in Champa, contributing to its expansion at the expense of both Tonkin and Angkor. The Central Vietnam coast is protected from the western monsoon by the Annamite Mountains, while the Central coast typically receives significantly less rain from the east than does Northern Vietnam. The smaller population in Champa relied less heavily on a complex system of irrigation works than the Red River, where dykes were built and extended over centuries and a complex system of local government was charged with maintenance and adjudication of local affairs. To the extent that deforestation of the series of short east-west rivers along the Champa coast was less severe in the 14th century than it became in later eras, the populations living along them enjoyed a greater degree of protection from damage by flash floods. In 1414, Ming records describe Cambodia presenting a complaint reporting that Champa had attacked it repeatedly, and by 1421 a Champa ruler asserted control over Angkorian territory along the Dong Nai River above Saigon (Vickery, 2011). A combination of natural and man-made factors protected the Dong Nai region from flooding and the effects of drought. A dense, natural forest cover above Bien Hoa intercepted and retained water on the landscape, thereby preventing the 
massive runoff and erosional problems experienced in the denuded Kulen Hills above Angkor, while a series of natural and man-made lakes served to store water for times of deficit while mitigating the impacts of floods.

The MADA reconstructions for Northern Vietnam suggest a similar but less severe pattern to Angkor, with a dry period in the late 15th century followed by a short burst of higher precipitation (Fig. 12). In 1471 Champa suffered a major military defeat when Tonkin, allied with one Champa faction, seized northern Champa territories in Quang Nam and Quy Nhon. Rather than continuing expansion to the south, Tonkin then concentrated its resources on the western highlands, which allowed Champa to become partially resurgent in the early 16th century. Soon after, northern Champa territories morphed into the autonomous kingdom of Cochinchina. The Hanoi chronicle mentions drought in 1440, 1448-49, 1463, 1467-68, 1473, 1476, 1480, 1488-89, 1497, 1499, 1503 and 1512, but also intermittent floods in $1440,1443,1445$ and in eight years between 1473 and 1503, and floods in four consecutive years from 1513 to 1516 . By this point the Le Dynasty had lost control of the northern Tonkin coast and would soon be replaced by the usurping Mac Dynasty. It should be noted, however, that the chronicle also references drought seven times between 1525 and 1589 and also in each year from 1594 to 1599, with floods in 1596-97, a period for which the MADA suggests higher than average precipitation.

\subsection{Descriptions of 17 th century climate instability in Tonkin}

Droughts in Tonkin are referenced more rarely in the Hanoi chronicle during the 17th century, in 1608, 1616, 1622, 1629, 1634, 1669 and 1675, while floods are mentioned only in 1617, 1630,1681 and 1695. However, the MADA indicates that the climate across Southeast Asia during the 17th century was among the most variable of the past 700 years. The poor accuracy of the Hue chronicle's eclipse reports for the 17th century suggests it may not provide a wholly reliable account in this period. Still, drought is mentioned in $1608,1629,1641,1668$ and 1689 . Floods and storms are described as aiding Cochinchina's troops in battles near the Tonkin border in 1657 , and floods are also mentioned in 1663, 1671, 1676, 1686, 1691 and 1694 (Fig. 12 a). The fact that there are relatively few descriptions of climate extremes in Hanoi does not mean that they did not occur, but rather that few local records of their social and political significance have survived. Early Jesuit missionaries reported
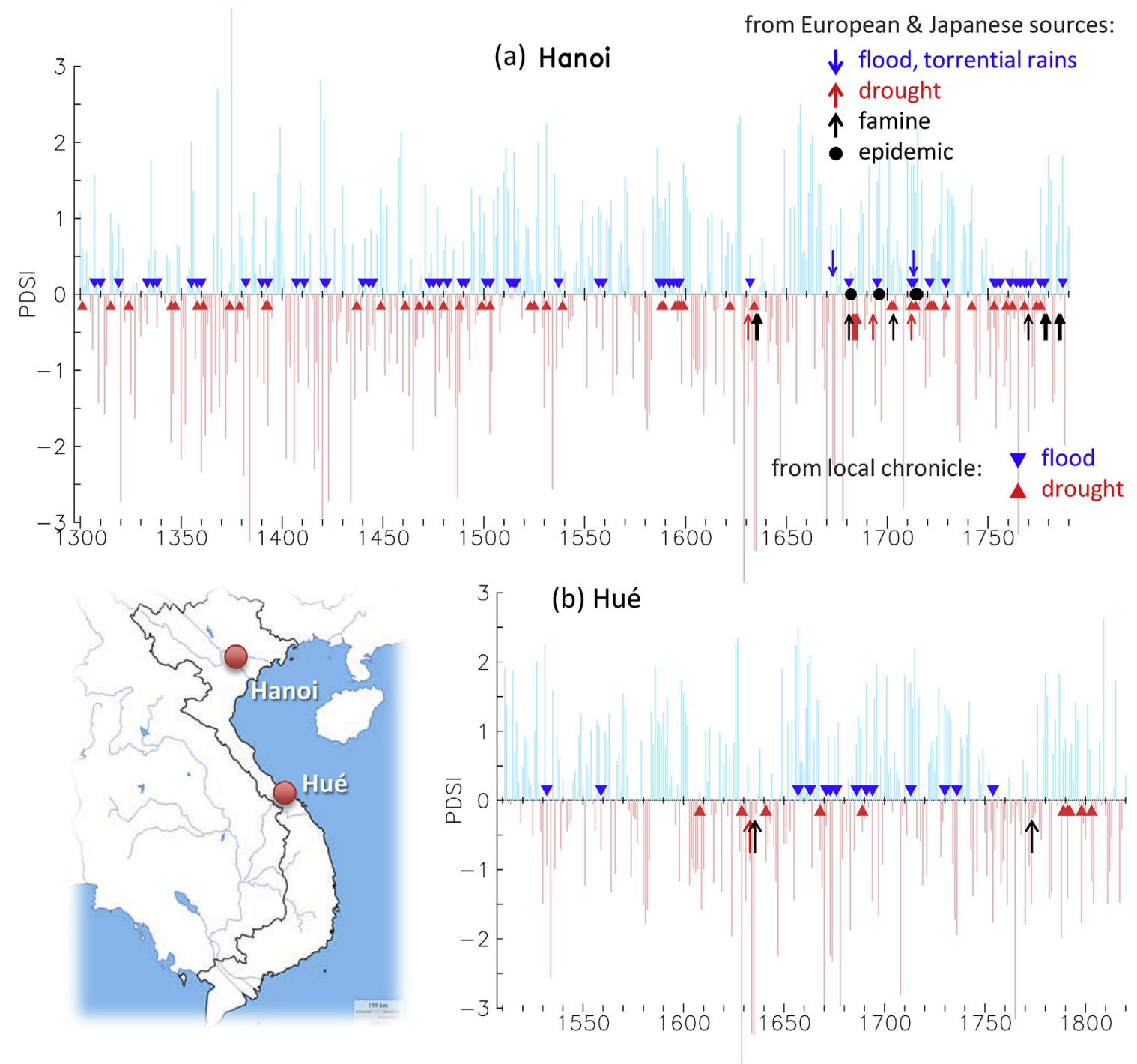

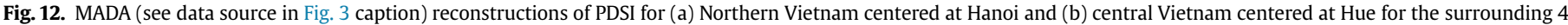

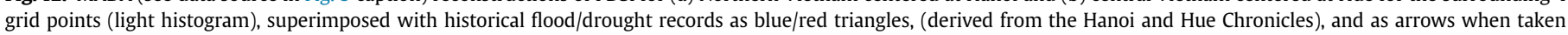
from European sources as described in the text. The black circles refer to periods of severe famine as reported by several sources. 
that Tonkin suffered from severe drought in 1631, while drought occurred in Cochinchina in 1634 with significant loss of harvests. Famine spread across Tonkin by 1635 and 1636 (Tavares Mourão, 2005), much as it had at least through 1635 in Burma (Lieberman and Buckley, 2012). The Hanoi chronicle does not dwell on Tonkin famine, but does contain a reference to a 1637 famine in Cochinchina.

A second severe period of multi-decadal drought is evident from the MADA in both North and Central Vietnam in the late 17th century, peaking around the time of the 1689 drought mentioned in the Hue chronicle. Dutch and British merchants in Tonkin reported heavy rains and floods in 1641, 1649 and 1653-54, but drought in 1664. Hanoi's rulers ordered dyke repairs seven times between 1660 and 1673, and in 1673 two provinces were flooded to save the town of Pho Hien (Iioka, 2009). Tonkin missionaries and merchants reported a drought that led to a famine from 1681 to 82 (Farrington, 1994; Forest, 1998) and an observer in the employ of the East India Company later claimed that a few million people perished (Dror and Taylor, 2006). The Japanese shipping record Kai Hentai described drought in 1681 that brought Tonkin three years of famine, with floods in 1682-85, an epidemic in 1682, and drought in 1685 and 1693 (Iioka, 2009). In 1681-82, Kai Hentai described serious famine and a smallpox epidemic in Siam (Ishii, 1998). Tonkin missionaries reported famine and an epidemic in 1696 (Forest, 1998). Although famine and epidemics left Tonkin without sufficient manpower to maintain its damaged dykes, the ruling regime was able to stay in power.

A new Cochinchina capital was created in Hue in the 1680s with the participation of "Ming Loyalist" migrants who were exiled following the Qing Dynasty's consolidation of control over the South China coast and Taiwan in the 1680s. These forces then reached past the rump kingdom of Champa, which existed in a diminished form in Phan Rang and the hills to its west, and formed Cochinchinese and "Ming Loyalist" colonies in Dong Nai and the Lower Mekong Delta. There is a striking parallel between Cochinchina's move into Dong Nai at this time and Champa's move to the same location by the early 15 th century. Although the Hue chronicle did not explicitly link these movements to climate, it emphasized that Dong Nai was strategically important during the 18th century wars because it was less susceptible to both drought and flooding. This must have been true in earlier centuries as well.

\subsection{A tumultuous 18 th century across Southeast Asia}

The drought-prone 18th century was one of great societal turmoil across all of South and Southeast Asia as described previously in this paper, as well as in northern Eurasia (Kahan, 1985; Lieberman, 2003). In the Hanoi chronicles, references to drought appear with increasing frequency in the 18th century: 1702, 1703, 1712-14, 1721-23, 1729, 1742, 1753, 1755, 1759, 1761-62, 1765, 1774 and 1776 . Floods are also reported regularly, in 1712-13, 1721, 1725, 1729-30, 1735, 1753-54, 1756-57, 1761, 1764, 1766, 1767-69, 1771$72,1776,1778$ and 1787 (on the eve of Tonkin's fall to the Tay Son). In 1776, three years after Tonkin's occupation of Hue, Hanoi's rulers are described conducting a ceremony to bring rain. Tonkin missionaries describe a 1703 famine that caused the death of almost half the population of some provinces, a 1712 drought, 1713 floods due to dyke breaches, as well as famine and an epidemic in 171415.

The Hue chronicle, in stark contrast, does not mention drought until after 1788 (Fig. 12 b), when Nguyen Anh established Saigon as a rival capital in Cochinchina. However, descriptions of floods are noted in 1713, 1730, 1736 and 1754, and in 1732 in Cambodia. In 1789 , the new Saigon regime sent rice to Siam to alleviate the effects of a drought there that drove up the price of rice in Saigon in
1791. A Bangkok Royal chronicle also described high water, a failed rice crop and high prices in 1785 (Flood and Flood, 1978). The Hue chronicle described drought as a significant factor in the military campaigns of Nguyen Anh, stating that the Tay Son-held Binh Thuan Province was abandoned upon his arrival there in 1794 due to years of drought, and faced drought again in 1798. On the eve of Nguyen Anh's defeat of the Tay Son in 1801 other parts of the Center are said in the Hue chronicle to have faced years of drought and lost harvest.

The French observer Turpin (1771) reported that the most crippling drought and famine in Ayutthaya had occurred around the beginning of the 18th century, though he did not know the precise year. The Burmese are reported to have amassed more than 350,000 troops to lay siege to Ayutthaya in 1767 , and it is likely that the effects of drought enabled such large numbers of troops to amass on the wetlands surrounding that city. Turpin attributed famine at the time of the Burmese invasion to disruption of agriculture and crop-burning by occupying troops, noting that the land was still fertile enough that even with farmers forbidden to work their fields, some crops could still grow abundantly. When King Taksin recaptured Ayutthaya, he reportedly led an expedition to retake Chiang Mai only to find that the city lay abandoned for the duration of the worst of the Strange Parallels Drought (Fig. 4 c) (Wyatt and Wichienkeeo, 1998).

The collapse of the Cochinchina regime circa 1773-74 and its division between Tay Son and Tonkin forces may also have been related to the cumulative effects of drought. Notably, the Cochinchina rulers' last holdout against the Tay Son was again in Dong Nai, and they returned to hold Saigon and Dong Nai within a few years. Dutton (2006) noted Chapman's (1778) account of a famineweakened Central Vietnam. War, crop burning, and Hue being cut off from regular rice imports from Saigon and Dong Nai may have contributed to the famine. However, Chapman's report of human flesh sold in markets might have been exaggerated to support his campaign to urge the British to seize power.

Tonkin missionaries described food shortages in 1770, 1778-79 and in 1785-86 (Forest, 1998). In 1786, a missionary described the wealthy barricaded into their homes to hoard stockpiles of food (Dutton, 2006). Another complained in 1789 "And what has this [horrible war] produced? Famine, pestilence, deaths of people and livestock, and all of this without remedy." These descriptions suggest that the Strange Parallels drought was felt as strongly in Tonkin as it was in the rest of the region, and raise the question of whether chronic failures in water management contributed to their defeat by the Tay Son. As Turpin (1771) commented on the climate of Tonkin: "It is true that at times the land is stricken with sterility. The floods destroy the young crops and the drought [that is, the dry season] changes the fertile earth into arid dust."

\section{Variability of the monsoon - dynamical explanations}

\subsection{Seasonal evolution of the monsoon}

In the beginning of this paper we offered a fairly simplified description of the monsoon, but there is significant debate about how to accurately define the monsoon, and how to establish a clear determination of its onset and withdrawal with any degree of certainty (see, discussions in Wang and LinHo, 2002; Zhang et al., 2004; Cook and Buckley, 2009). Zhang et al. (2004) define the Asian Summer Monsoon evolution and mechanics through analyses of atmospheric dynamics that encompass large-scale circulation parameters such as meridional temperature gradient of the troposphere and the establishment of an easterly vertical wind shear, both due to upper level warming caused by the convective transport of latent heat. Their study illustrates that the earliest onset of 
the broad monsoon begins over the Indochina Peninsula, following developments over the Indian Ocean and the Bay of Bengal.

The monsoonal southwesterly winds first develop during the month of May and trigger the monsoon flow-terrain interaction in western Myanmar and western Thailand, thus signifying the monsoon onset in that particular region (Fig. 13 a) (Wang et al., 2013). Meanwhile India remains rather dry under the predominant northwesterly flows. This situation changes in June (Fig. 13 b) when the cross-equatorial monsoon flow quickly intensifies and expands northward, bringing moisture over the southern part of India and initiating the Indian Summer Monsoon (ISM) onset from south in early June to north in late June. The intensified monsoon westerlies penetrate the Indochina Peninsula into the South China Sea, staging the monsoon onset there (e.g., Wang, 2006). During July and August (Fig. 13 c) after the ISM reaches the mature stage with widespread monsoon rains over India, the westerlies further extend into the western tropical Pacific with the northward displacement of the easterly Trade Wind. At this stage the Western North Pacific Summer Monsoon (WNPSM) reaches its highest intensity while tropical cyclonic activity increases dramatically (e.g., Chen et al., 2004b).

Beginning in mid-September, the intensity of the westerly and southwesterly monsoon flow decreases rapidly and by October has completely withdrawn (Fig. 13 d). What replaces the southwesterly monsoon in East Asia is the development of northeasterly flow associated with the cooling and high-pressure system developing over mainland East Asia, centered in Siberia. The cool, relatively dry northwesterly winds out of the continent then travel a great distance over the ocean before encountering Vietnam (Fig. $13 \mathrm{~d}$ ), and consequently produce copious rainfall over coastal/central Vietnam that persists until December. Therefore, while the region surrounding Greater Angkor benefits from summer monsoon rains, for central Vietnam it is during the summer-winter transition of the monsoons that it receives the most rainfall. The latter might have shaped the development of the kingdoms that held dominion over the regions to the east of the Annamite Range, as discussed below.

\subsection{Climate oscillations}

As noted previously the Asian Summer Monsoon is affected by a number of "remote forcings" through the atmospheric teleconnection mechanism (e.g., ENSO, IPO). Such remote modulations occur through either the tropical east-west circulation (i.e., Walker Circulation) in response to tropical sea surface temperature (SST) and convective activity, or through a dispersion of atmospheric energy from the west and from higher latitudes forming the socalled Eurasian wave train (e.g., Ding and Wang, 2007). In some years, the two processes may either be in phase or out of phase leading to constructive or destructive influences on the monsoon rains, respectively. During the autumn season, ENSO affects the western tropical Pacific circulation and modifies the intensity and moisture content of the northeasterly monsoon flows toward Indochina and central Vietnam (Tsay, 2004). These climate oscillations are, therefore, of great concern to the human populations living within the monsoon's influence.

Fig. 14 shows the composite anomalous flows at the $700-\mathrm{mb}$ level (approximately $3000 \mathrm{~m}$ above sea level) between the El Niño (warm phase) and La Niña (cool phase) years, based upon the operational ENSO index provided by the NOAA Climate Prediction Center beginning in $1950 .{ }^{1}$ The wind data here are obtained from the NCEP/NCAR Reanalysis (Kalnay et al., 1996). Over the Indochina

\footnotetext{
1 http://www.cpc.ncep.noaa.gov/products/analysis_monitoring/ensostuff/ ensoyears.shtml.
}

(a) May

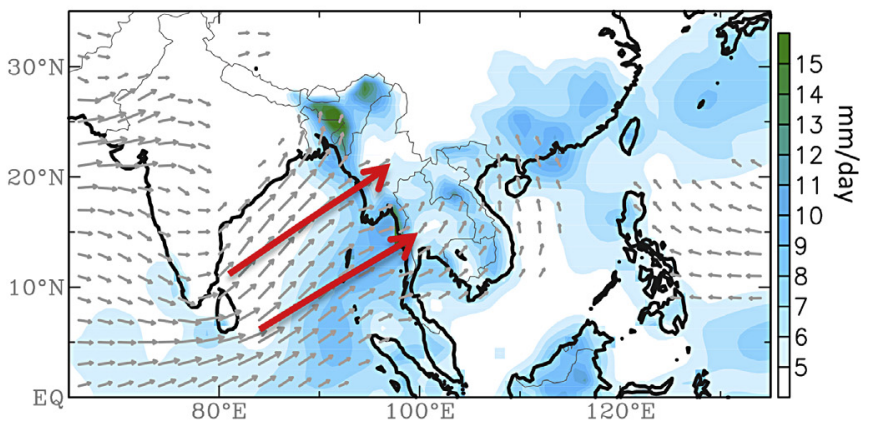

(b) June

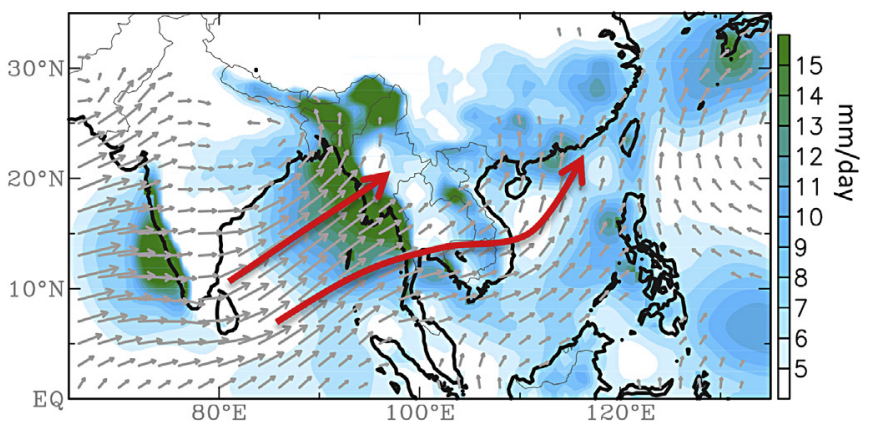

(c) August

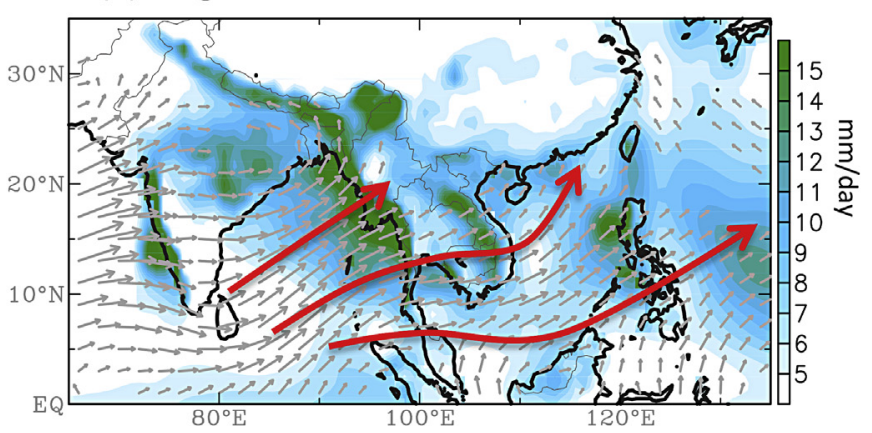

(d) October

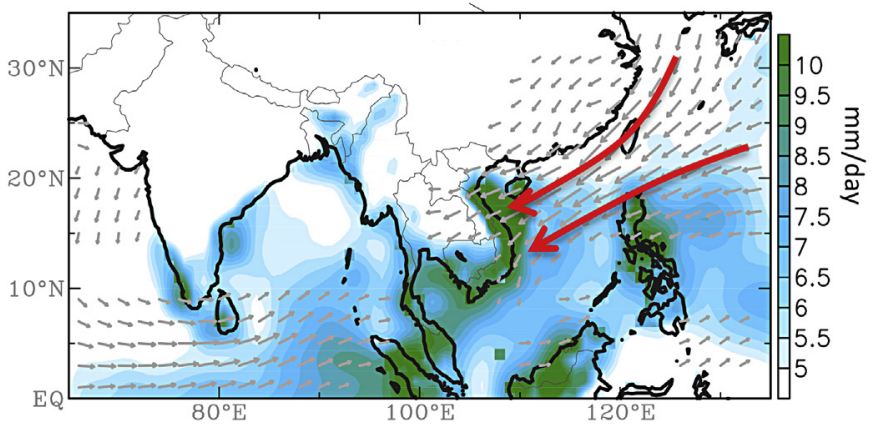

Fig. 13. Monthly wind climatology (vectors from the NCEP/NCAR Reanalysis) at the 850-mb level or about $1500 \mathrm{~m}$ altitude, superimposed with precipitation - Global Precipitation Climatology Centre (GPCC) over land and Global Precipitation Climatology Project (GPCP) data over the oceans - for (a) May, (b) June, (c) August and (d) October. Red arrows indicate the main direction and extension of the major monsoonal flows. Shadings are precipitation from GPCC over land and GPCP over the oceans (see Fig. 1 caption).

Peninsula an anomalous anticyclone develops during El Niño years leading to widespread dry conditions. The composite PDSI (shading over land) corresponds to this anticyclonic circulation with pronounced and expansive drought conditions. Likewise, a cyclonic 


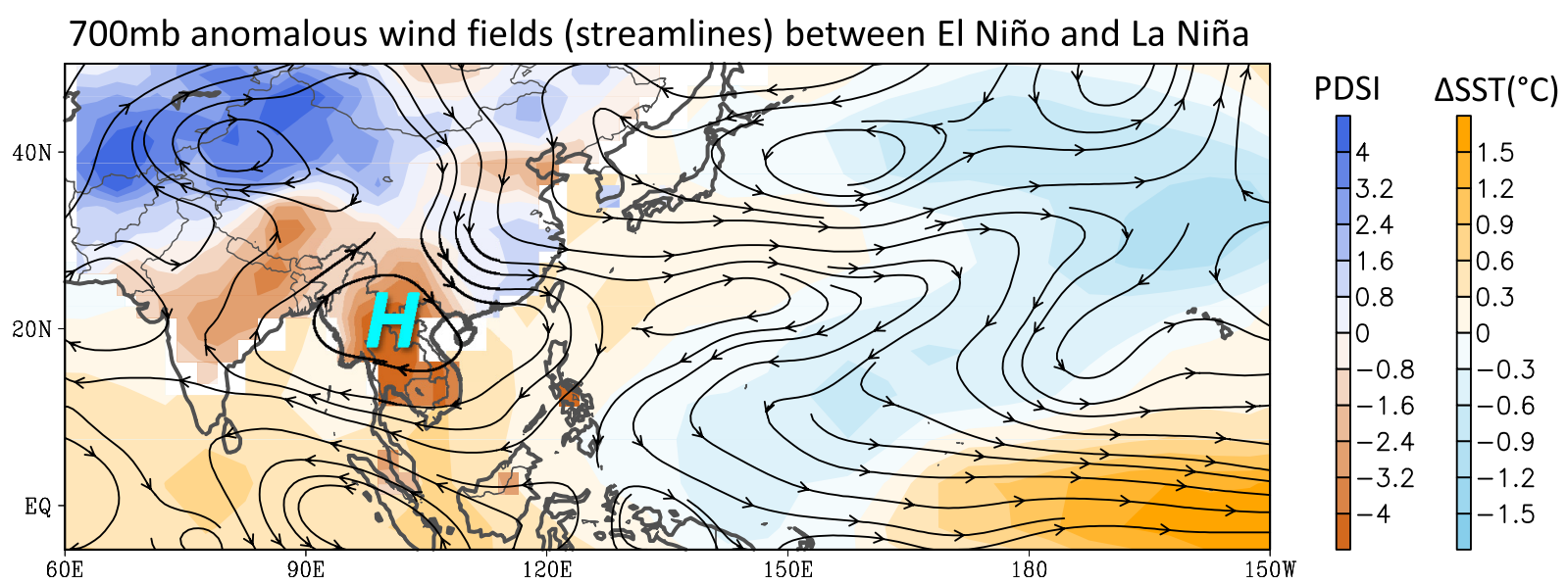

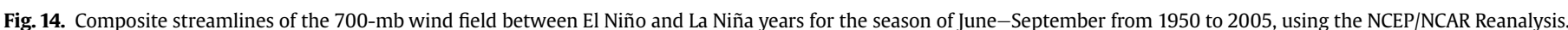

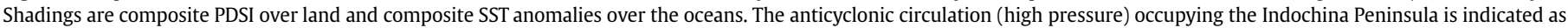

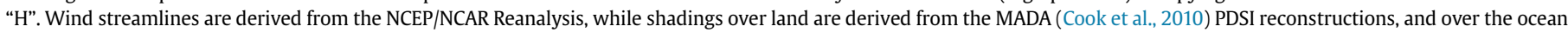
from the NOAA Optimum Interpolation Sea Surface (SST) Temperature V2.

circulation develops during La Niña years causing wet conditions. The SST anomalies using the Kaplan SST data (Reynolds and Smith, 1994) depict the classic eastern tropical Pacific 'warm tongue' of El Niño associated with the broad cyclonic circulation in the subtropics. Thus, the regional circulation change over Indochina is apparently a teleconnectional process in response to the eastern tropical Pacific warming and the broad subtropical cyclonic circulation. Otherwise, the Indian Ocean warming as shown in Fig. 14 should have favored a locally induced cyclonic circulation over Indochina and India.

\subsection{Weather extremes}

Summer rainfall on the Indochina Peninsula has two main origins - (a) steady monsoon rain caused by terrain-flow interaction and enhanced diurnal convection, and (b) torrential rain brought in

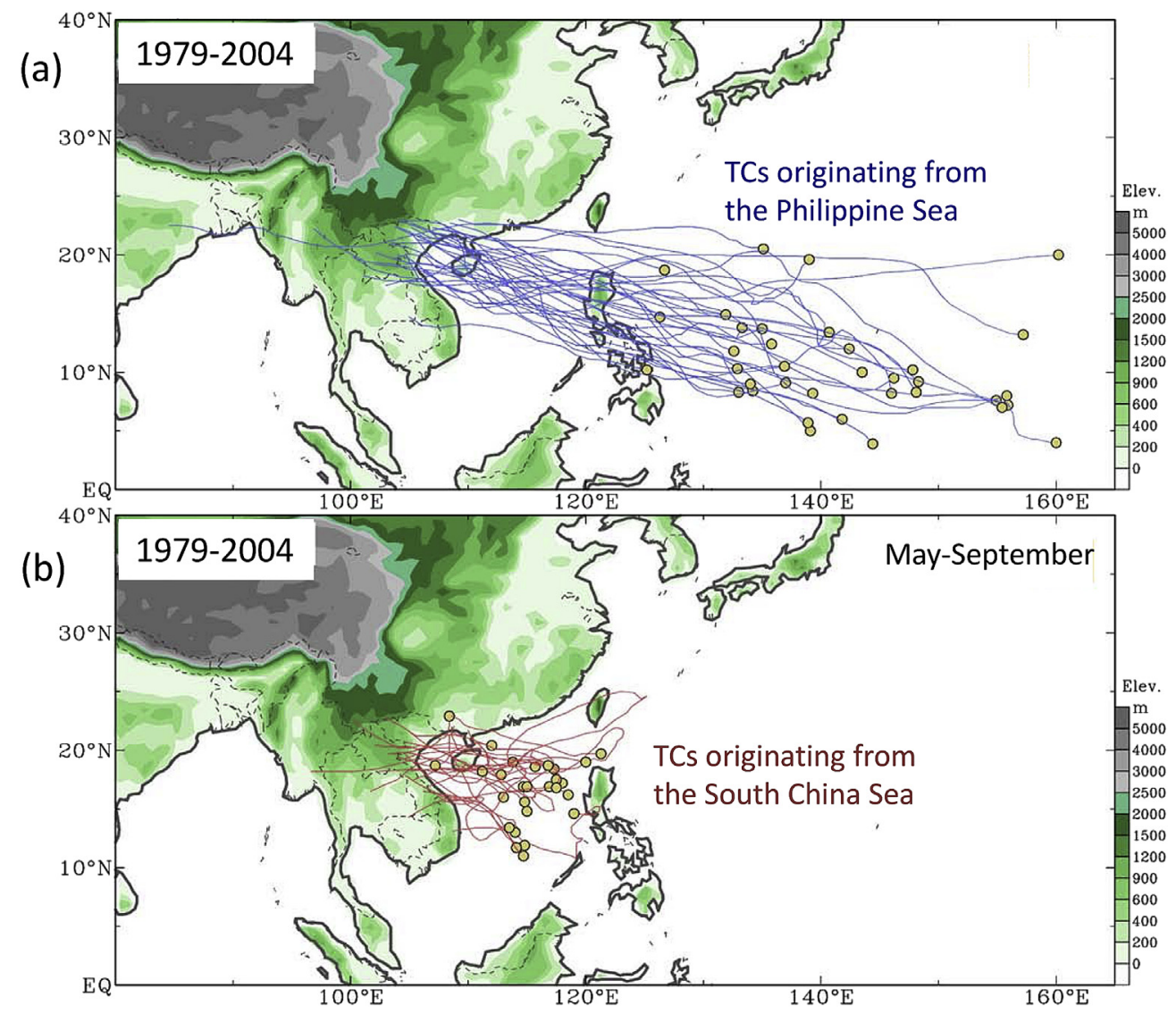

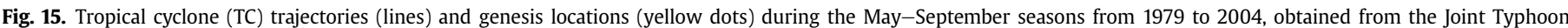

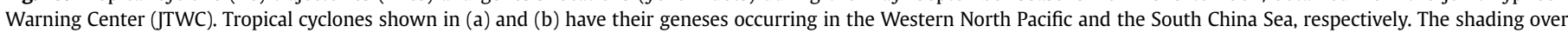
land indicates topography. Shadings over land are USGS digital Elevation Model $0.25^{\circ}$ topography. Tropical cyclone tracks are from the Joint Typhoon Warning Center (JTWC). 
by tropical disturbances (Chen and Yoon, 2000). Neighboring the western tropical Pacific, the world's largest breeding area for tropical cyclones, Indochina receives its share of tropical cyclones. The Western Pacific tropical cyclones almost always propagate towards the west once they form, following the tropical easterly winds that steer them. These storms can then turn northward if they encounter mid-latitude frontal systems, or they may continue to move westward across the South China Sea, into Indochina or southern China. Fig. 15 a shows the tracks of tropical cyclones during the warm season (May-September) of 1979-2004, obtained from the Joint Typhoon Warning Center (JTWC). It is apparent that tropical cyclones can and do penetrate far inland into Indochina. Tropical cyclones also form in the South China Sea (SCS) (Fig. 15 b), and in fact, SCS tropical cyclones have a greater tendency to propagate westward into Indochina than their Western Pacific counterpart (Liu and Chan, 2003).

When tropical cyclones reach mainland Southeast Asia, their intensity in terms of wind speed decreases and they are downgraded from cyclone status and become what are known as residual lows (Yoon and Chen, 2005). Although not fierce in wind power, these residual lows contain as much moisture as a tropical cyclone and continue to produce large amounts of rainfall as a slowermoving storm system, dumping copious amounts of rain for an average duration of 3-4 days. Yoon and Huang (2012) have noted that residual lows coming from tropical cyclones and equatorial easterly waves (i.e., a type of tropical weather system not strong enough to be declared a tropical cyclone but associated with organized convective clouds) contribute to about $50 \%$ of the warm season rainfall over Indochina. The previously mentioned climate oscillations like ENSO have a direct modulating effect on the residual low activity as well (Chen and Yoon, 2000). Yet, even though an El Niño (warm phase of ENSO) reduces the seasonal number of tropical cyclones, it does not eliminate them. Tropical cyclones and easterly waves still may form and propagate into Indochina. Perhaps more importantly, any changes in the residual low activity may impose a stronger effect on the wet/dry climate anomalies over Indochina as such storms are the only source in the region that can overwhelm any hydrologic system in a short period of time, regardless of the ENSO-monsoon status. It must therefore be considered that the source of large deluge events as recorded at Angkor, Hanoi and Hue, with their impacts on infrastructure described in the sections above, may be derived from an increase in tropical cyclonic activity, and are not derived from an increase in monsoon strength per se.

\subsection{An explanation for persistent drought over Indochina}

In Fig. 14 we illustrated the well-known impact of ENSO on the climate of Indochina. Anomalous conditions in response to El Niño/
La Niña occur mostly at the interannual (year-to-year) timescale. However, ENSO also exhibits a broad, lower-frequency energy spectrum at the decadal scale (Zhang and Levitus, 1997; Zhang et al., 1997). An example is the Interdecadal Pacific Oscillation (IPO), which imposes a basin-scale interdecadal variability (Folland et al., 2002). Buckley et al. (2010) found that southern Vietnamese treering records respond with remarkable fidelity to the IPO index, acquiring a correlation coefficient of 0.673 (Fig. 16). In fact, the relationship was so stable it allowed for a successfully calibrated and verified reconstruction following standard dendroclimatological procedures (see Buckley et al., 2010 Supplementary Online Material for details). This strong relationship is indicative that climate over Indochina not only responds to the interannual ENSO variation but also reflects the decadal-scale variability of the IPO, belying the region's susceptibility to persistent phases of either El Niño or La Niña over an extensive period of time. The two Victorian droughts depicted in Fig. 4 present a great example of what might be termed "normal" El Nino conditions. The Strange Parallel Drought of the 18th century, however, was a persistent multi-decadal drought that is more indicative of the lower frequency expressions of El Niño. The possibility of this type of extended drought occurring with current population density is a real cause for concern.

Drought over Indochina may also be the result of climate forcing other than ENSO. For instance, Fig. 17 a shows the second leading mode of the empirical orthogonal function (EOF) applied on the combined MADA and the North American Drought Atlases (NADA; Cook et al., 2004) over the 730 years of the common MADA-NADA time period. (Note: the first mode responds closely to ENSO and the IPO that commonly results in opposite climate anomalies between South Asia and North America; not shown). This second mode of EOF (EOF2) of the MADA-NADA data reveals the same phase in South Asia and North America and explains about $11 \%$ of the total variance. Preliminary analysis not presented in this paper indicates that the EOF2 responds to an overall tropical warming/cooling of SST, in contrast to the eastern Pacific warming or cooling. When compared to the two historical Angkor droughts (Fig. $17 \mathrm{~b}$ and c), the spatial pattern of drought over the two main continents appears similar - i.e., both show the same phase of drought over much of North America. This is suggestive that the climatic conditions represented by EOF2 may have contributed to the formation of the two Angkor droughts, and that this pattern is not common over the period of record. Future research on the dynamic process leading to this EOF2 of drought is paramount.

\section{Conclusions}

Paleo-proxy records display periods over the past millennium where the strength and/or intensity of the Asian monsoon have
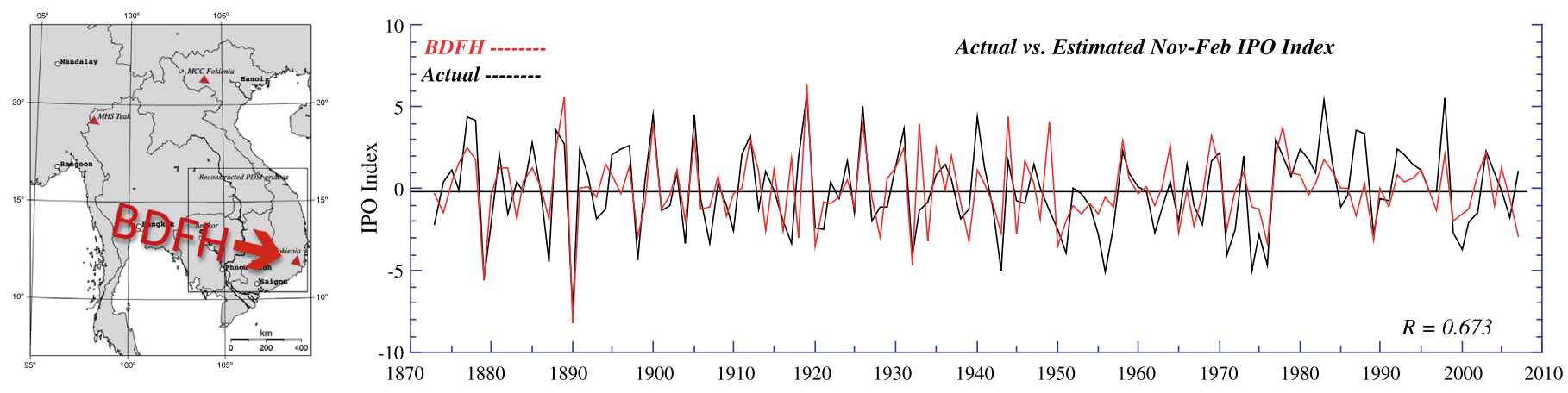

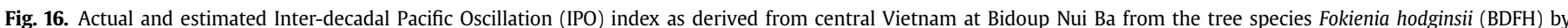

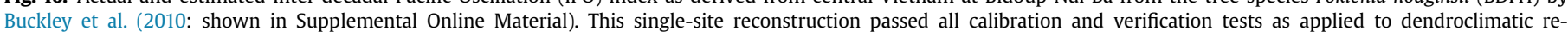
constructions, indicating the resonance of this region with the influence of the IPO. 
(a)EOF2 11.1\%

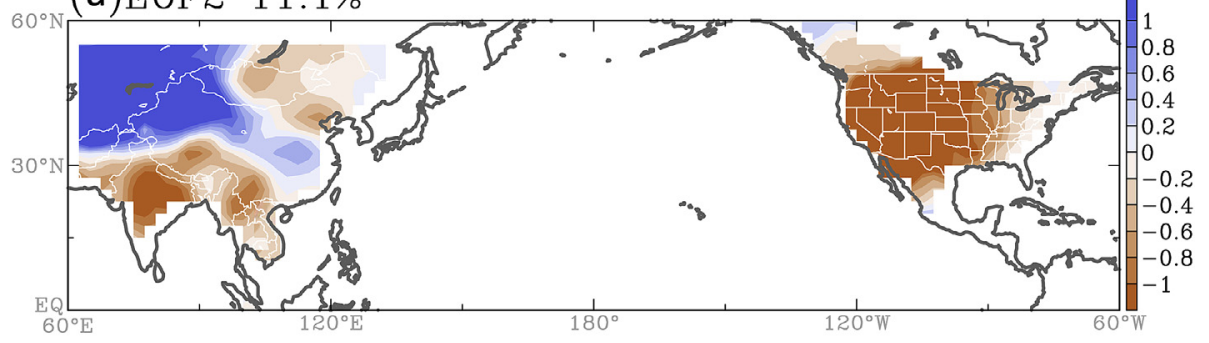

(b) 1345-1374: Angkor Drought I
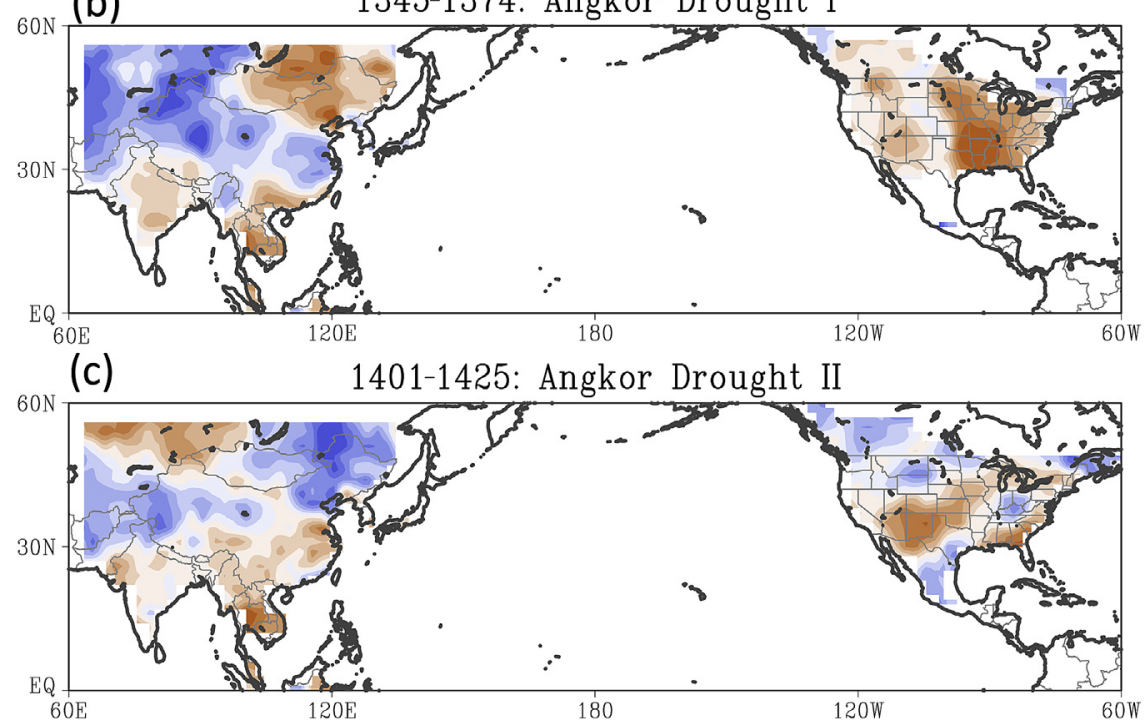

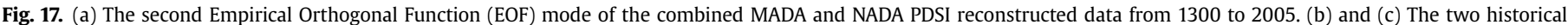

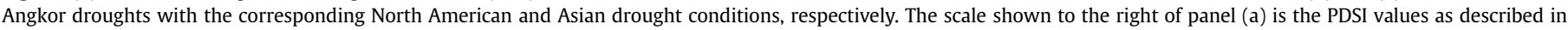
Fig. 4.

varied significantly, causing periods of prolonged droughts and seasons of anomalously high rainfall. Several of these periods coincided with times of the region's most epic societal struggles. In the case of the Khmer at Angkor we present evidence that extreme dry and wet conditions occurred alternately during a prolonged period of instability at the MWP-LIA transition in the late 14th and early 15th centuries. While both extremes had deleterious consequences, we conclude that it was the high magnitude wet events that irreparably damaged Angkor's aging hydro-management infrastructure, and thus necessitates a reappraisal of the context in which the ruling elite left the capital, and the sequence of events that led to its ultimate abandonment. This period also coincided with the end of the Mongolian-ruled Yuan Dynasty in China, and a period of instability in the Tonkin and Champa kingdoms in present-day Vietnam. The effects of drought during the late 14th century are described in chronicles as affecting regions as far away as Sri Lanka, and northern Vietnam's labor-intensive system of dykes was particularly vulnerable when droughts were followed by periods of high rainfall, flooding and epidemics. The latter half of the 18th century was notable for persistently weak monsoon rains that affected South and Southeast Asia for decades at a time, with millions of deaths recorded from India and Bengal to Vietnam, and political turmoil across mainland Southeast Asia. The dynamical causes of the climate anomalies described above are many, but the primary influence for Southeast Asia is ENSO, with warm phase events (El Niño) leading to weakened rainfall, and cold events (La Niña) leading to wetter than average conditions. Periods of anomalous climate that spanned decades are linked to the most tumultuous periods over the past millennium, and these are linked to lower-frequency phenomena like the IPO.

The Angkor Droughts, however, appear to originate from a different set of forcing factors, as the EOF analyses of the MADANADA suggest, and does not appear to be a common pattern of climate related to the various expressions of ENSO-related variability. Epic droughts aside, we conclude that it was the large magnitude rain events that occurred in the 14th and early 15th centuries that delivered crippling damage to Angkor's infrastructure, and these events were likely the result of tropical cyclonic activity in the South China Sea. To the east, over present day Vietnam, the kingdoms of Tonkin, Champa, and later Cochinchina also suffered the effects of drought and high magnitude rains that damaged infrastructure. As at Angkor the effects of climate were significant, and resulted in the reordering of political power in the late 14 th to early 15 th centuries, and again in the late 18th century in unison with the other dominant entities across Indochina.

If there is one thing that the Southeast Asian examples highlighted in this paper show, is that a critical factor in the magnitude of the impact of climatic instability has much to do with the internal specifics of the affected societies, including the condition and vulnerabilities of the material infrastructure and the pattern of social cohesion and tensions. Climate model predictions show little agreement with regard to future hydroclimate across South and Southeast Asia, painting an uncertain future (e.g., Annamalai et al., 2007). Anomalies of the sort that eroded the regional power of the Khmer kingdom in the 15th century, and reordered the power of all of Southeast Asia in the 18th century are clearly within the realm of possible outcomes in the near future, and must give us pause. 


\section{Acknowledgments}

This research was funded by the National Science Foundation Grants GEO 09-08971 and AGS 130-3976. The Greater Angkor Project at the University of Sydney is funded by grants from the Australian Research Council and National Geographic Committee for Research Exploration. The LiDAR survey was conducted for the eight institutions of the Khmer Archaeology LiDAR Consortium and partially funded by the Simone and Cino Del Duca Foundation and the National Geographic Committee for Research Exploration. Brian Zottoli's post-doctoral support comes from a Social Science Research Council Postdoctoral Fellowship for Transregional Research, with funds provided by the Andrew W. Mellon Foundation. S-Y Wang acknowledges support from the United States Agency for International Development grant EEM-A-00-10-00001, and from NASA Grant NNX13AC37G. The authors would like to thank Damian Evans, Chhay Rachna, Wayne Johnson and the many members of the University of Sydney's Greater Angkor Project team, our international collaborators at Ecole française d'ExtrêmeOrient, the APSARA National Authority of Cambodia, Professor Miriam Stark of the University of Hawaii, and Professor Rob Gillies of the Climate Center at Utah State University in Logan, Utah. Thanks also to the Robert Christie Research Centre and to the Faculty of Arts and Social Sciences, both of the University of Sydney. We also wish to thank two anonymous reviewers for their insightful comments and suggestions that improved the quality of our manuscript. Lamont-Doherty contribution number 7779.

\section{References}

Annamalai, H., Hamilton, K., Sperber, K.R., 2007. The south asian summer monsoon and its relationship with ENSO in the IPCC AR4 simulations. J. Clim. 20, 10711092.

Ashok, K., Guan, Z., Yamagata, T., 2001. Impact of the Indian Ocean dipole on the relationship between the Indian monsoon rainfall and ENSO. Geophys. Res. Lett. 28, 4499-4502.

Bamzai, A.S., Shukla, J., 1999. Relation between Eurasian snow cover, snow depth, and the Indian summer monsoon: an observational study. J. Clim. 12, 31173132.

Buckley, B.M., Anchukaitis, K.J., Penny, D., Fletcher, R., Cook, E.R., Sano, M., Le, C.N., Wichienkeeo, A., Ton, T.M., Truong, M.H., 2010. Climate as a contributing factor in the demise of Angkor, Cambodia. Proc. Natl. Acad. Sci. 107, 6748-6752.

Buckley, B.M., Palakit, K., Duangsathaporn, K., Sanguantham, P., Prasomsin, P., 2007. Decadal scale droughts over northwestern Thailand over the past 450 years and links to the tropical Pacific. Clim. Dyn. http://dx.doi.org/10.1007/s00382-0070225-1.

Chapman, C., 1778. A Narrative of the Occurrences in a Voyage to the Kingdom of Cochin-China. London.

Chen, T.-C., Yoon, J.-h., 2000. Interannual variation in Indochina summer monsoon rainfall: possible mechanism. J. Clim. 13, 1979-1986.

Chen, T.-C., Wang, S.-Y., Huang, W.-R., Yen, M.-C., 2004a. Variation of the East Asian summer monsoon rainfall. J. Clim. 17, 744-762.

Chen, T.-C., Wang, S.-Y., Yen, M.-C., Gallus, W.A., 2004b. Role of the monsoon Gyre in the interannual variation of tropical cyclone formation over the western North Pacific. Weather Forecast. 19, 776-785.

Clift, P.D., Plumb, R.A., 2008. The Asian Monsoon: Causes, History and Effects. Cambridge University Press, Cambridge, 270 pp.

Coe, M.E., 2003. Angkor and the Khmer Civilisation. Thames and Hudson, New York.

Coedès, G., 1913. Études cambodgiennes VIII, la fondation de Phnom Peñ au XVe siècle d'après la chronique cambodgienne. Bull. L'École Fr. d'Extrême-Orient 13 (6), 6-11.

Cook, B.I., Buckley, B.M., 2009. Objective determination of monsoon season onset, withdrawal and length. JGR-Atmos. 114, D23109 http://dx.doi.org/10.1029/ 2009JD012795.

Cook, E.R., Woodhouse, C.A., Eakin, C.M., Meko, D.M., Stahle, D.W., 2004. Long-term aridity changes in the western United States. Science 306 (5968), 1015-1018. http://dx.doi.org/10.1126/science.1102586.

Cook, E.R., Anchukaitis, K.J., Buckley, B.M., D’Arrigo, R.D., Wright, W.E., Jacoby, G.C., 2010. Asian monsoon failure and megadrought during the last millennium. Science 328 (5977), 486-489. http://dx.doi.org/10.1126/science.1185188.

Cook, E.R., Krusic, P.J., Anchukaitis, K.J., Buckley, B.M., Nakatsuka, T., Sano, M., 2013. Tree-ring reconstructed summer temperature anomalies for temperate East Asia since 800 CE. Clim. Dyn 41, 2957-2972.

Dai Nam Thuc Luc Tien Bien, 1844. Ms., École française d'Extrême-Orient.

Dai Viet Su Ky Toan Thu, 1697. École française d'Extrême-Orient.
Dagens, B., 2003. Les Khmers. Belles letters, Paris.

Day, M.B., Hodell, D.A., Brenner, M., Chapman, H.J., Curtis, J.H., Kenney, W.F. Kolata, A.L., Peterson, L.C., 2012. Paleoenvironmental history of the West Baray, Angkor (Cambodia). Proc. Natl. Acad. Sci. U. S. A. 109, 1046-1051.

Davis, M., 2001. Late Victorian Holocausts: El Niño Famines and the Making of the Third World. Verso Books.

Ding, Q., Wang, B., 2007. Intraseasonal teleconnection between the summer Eurasian wave train and the Indian Monsoon*. J. Clim. 20, 3751-3767.

Ding, Y., 2004. Seasonal march of the East-Asian summer monsoon. East Asian Monsoon 2, 30-53.

Dror, O., Taylor, K.W., 2006. Views of Seventeenth-Century Vietnam: Christoforo Borri on Cochinchina and Samuel Baron on Tonkin. Cornell University Southeast Asia Program Publications, 290 pp.

Dutton, G., 2006. The Tay Son Uprising: Society and Rebellion in Eighteenth Century Vietnam. University of Hawaii Press, 293 pp.

Evans, D., Pottier, C., Fletcher, R., Hensley, S., Tapley, I., Milne, A., Barbetti, M., 2007. A comprehensive archaeological map of the world's largest pre-industrial settlement complex at Angkor, Cambodia. Proc. Nat. Acad. Sci. 104, 1427714282.

Farrington, A., 1994. English east India company Documents relating to pho hien and Tonkin. In: Pho Hien, the Centre of International Commerce in the XVIIXVIIIth Centuries Association of Vietnamese Historians, People's Administrative Committee of Hai Hung Province. The Gioi Publishers, Ha Noi, pp. 148-161.

Fleitmann, D., Burns, S.J., Mangini, A., Mudelsee, M., Kramers, J., Villa, I., Neff, U., AlSubbarye, A.A., Buettner, A., Hippler, D., Matter, A., 2007. Holocene ITCZ and Indian monsoon dynamics recorded in stalagmites from Oman and Yemen (Socotra). Quat. Sci. Rev. 26, 170-188.

Fletcher, R.J., Barbetti, M., Evans, D., Than, H., Sorithy, I., Chan, K., Penny, D. Pottier, C., Somaneath, T., 2003. Redefining Angkor: structure and environment in the largest, low density urban complex of the pre-industrial world. UDAYA 4 107-121.

Fletcher, R., Penny, D., Evans, D., Pottier, C., Barbetti, M., Kummu, M., Lustig, T. APSARA, 2008. The water management network of Angkor, Cambodia. Antiquity $82,658-670$.

Flood, E.T., Flood, C., 1978. The Dynastic Chronicles, Bangkok era, the First Reign. Translation of Thiphakonwongmahakosathibodi Chaophraya. Center for East Asian Cultural Studies, Tokyo.

Folland, C.K., Renwick, J.A., Salinger, M.J., Mullan, A.B., 2002. Relative influences of the interdecadal Pacific oscillation and ENSO on the south Pacific convergence zone. Geophys. Res. Lett. 29, 1643.

Forest, A., 1998. Les missionnaires français au Tonkin et au Siam, XVIIe - XVIIIe siècles. L'Harmattan, Paris, p. 461.

Goswami, B.N., Madhusoodanan, M., Neema, C., Sengupta, D., 2006. A physical mechanism for North Atlantic SST influence on the Indian summer monsoon. Geophys. Res. Lett. 33.

Groslier, B.P., 2006. Angkor and Cambodia in the Sixteenth Century (M. Smithies, Trans.). Orchid Press, Bangkok.

Hahn, D.G., Shukla, J., 1976. An apparent relationship between the Eurasian snow pack and Indian monsoon rainfall. J. Atmos. Sci. 33, 2461-2462.

Harris, P., 2007. A Record of Cambodia. The Land and the People. Silkworm Books, Thailand.

Harris, I., 2008. Buddhism in Cambodia. University of Hawai'i Press, Honolulu.

Hawken, S., 2011. Metropolis of Ricefields: a Topographic Classification of a Dispersed Urban Complex (Ph.D thesis). University of Sydney.

Heng, H.L., 2002. Angkor revisited: lessons to learn. SPAFA J. 9, 5-14.

Hoskins, B., Wang, B., 2006. Large-scale Atmospheric Dynamics. The Asian Monsoon. Springer, pp. 357-415.

Iioka, N., 2009. Literati Entrepreneur: Wei Zhiyan in the Tonkin-Nagasaki Silk trade (Ph.D dissertation in History). National University of Singapore.

Ishii, Y., 1998. The Junk Trade from Southeast Asia: Translations from the Tôsen Fusetsu-gaki, 1674-1723. Institute of Southeast Asian Studies, National University of Singapore, p. 282.

Kahan, A., 1985. The Plow, Hammer and Knout: an Economic History of Eighteenthcentury Russia. University of Chicago Press, Chicago, 399 pp.

Kalnay, E., Kanamitsu, M., Kistler, R., Collins, W., Deaven, D., Gandin, L., Iredell, M. Saha, S., White, G., Woollen, J., Zhu, Y., Chlliah, M., Ebisuzaki, W., Higgins, W., Janowiak, J., Mo, K.C., Ropelewski, C., Wang, J., Leetmaa, A., Reynolds, R. Jenne, R., Joseph, D., 1996. The NCEP/NCAR 40-year reanalysis project. Bull. Am. Meteor. Soc. 77, 437-471.

Krishnamurthy, V., Goswami, B.N., 2000. Indian monsoon-ENSO relationship on interdecadal timescale. J. Clim. 13, 579-595.

Kumar, K.K., Rajagopalan, B., Cane, M.A., 1999. On the weakening relationship between the Indian monsoon and ENSO. Science 284, 2156-2159.

Kutzbach, J.E., 1981. Monsoon climate of the early Holocene: climate experiment with the Earth's orbital parameters for 9000 years ago. Science 214 (4516), 5961.

Lamb, H.H., 1965. The early medieval warm epoch and its sequel. Palaeogeogr. Palaeoclimatol. Palaeoecol. 1, 13 http://dx.doi.org/10.1016/0031-0182(65) 90004-0.

Lieberman, V., 2003. Strange Parallels: Southeast Asia in Global Context, c. 800 1830. Cambridge University Press, Cambridge, 484 pp.

Lieberman, V., Buckley, B.M., 2012. The impact of climate on Southeast Asia c. 950 1820: new findings. Mod. Asian Stud., 1-48 http://dx.doi.org/10.1017/ S0026749X12000091. 
Liu, K., Chan, J.C., 2003. Climatological characteristics and seasonal forecasting of tropical cyclones making landfall along the South China coast. Mon. Weather Rev. 131, 1650-1662.

Lombard, D., 1970. Pour une histoire des villes du Sud-Est asiatique. Annales 25, $842-856$.

Maher, B.A., 2008. Holocene variability of the East Asian summer monsoon from Chinese cave records: a re-assessment. Holocene 18 (6), 861-866.

Meehl, G.A., Hu, A., 2006. Megadroughts in the Indian monsoon region and southwest North America and a mechanism for associated multidecadal Pacific sea surface temperature anomalies. J. Clim. 19, 1605-1623.

Moberg, A., Sonechkin, D.M., Holmgren, K., Datsenko, N.M., Karlen, W., 2005. Northern hemisphere annual temperatures from low- and high-resolution proxy data over the last 2000 years. Nature 433 (7026), 613-617.

Molnar, P., 2005. Mio-Pliocene growth of the Tibetan Plateau and evolution of East Asian climate. Palaeontol. Electron. 8 (1), 23, 2 A.

Neelin, J.D., 2007. Moist dynamics of tropical convection zones in monsoons, teleconnections and global warming. In: Schneider, T., Sobel, A. (Eds.), The Global Circulation of the Atmosphere. Princeton University Press, , Princeton, NJ pp. 267-301.

Ngo, T.L., Nguyen, K.H., 1991. Dai Viet Su Ky Tuc Bien (1767-1789). Social Science Publishing House, Hanoi, p. 483.

Penny, D., Pottier, C., Kummu, M., Fletcher, R., Zoppi, U., Barbetti, M., Tous, S., 2007 Hydrological history of the West Baray, Angkor, revealed through palynological analysis of sediments from the West Mebon. Bull. l'École Fr. d'Extrême-Orient 92, 497-521.

Reynolds, R.W., Smith, T.M., 1994. Improved global sea surface temperature analysis using optimum interpolation. J. Clim. 7, 929-948.

Sachs, J.P., Sachs, D.E., Smittenberg, R.H., Zhang, Z., Battisti, D.S., Golubic, S., 2009. Southward movement of the Pacific intertropical convergence zone AD $1400-$ 1850. Nat. Geosci. 2, 519-525.

Sinha, A., Stott, L., Berkelhammer, M., Cheng, H., Edwards, R.L., Buckley, B.M., Aldenderfer, M., Mudelsee, M., 2010. A global context for megadroughts in monsoon Asia during the past millennium. Quat. Sci. Rev. http://dx.doi.org 10.1016/j.quascirev.2010.10.005.

Sodhi, N.S., Koh, L.P., Brook, B.W., Ng, P.K.L., 2004. Southeast Asian bioldiversity: an impending disaster. Trends Ecol. Evol. 19 (12) http://dx.doi.org/10.1016/ j.tree.2004.09.006.

Sonnemann, T., 2011. Angkor Underground - Applying GPR to Analyse the Diachronic Structure of a Great Urban Complex (Ph.D thesis). University of Sydney, Sydney, Australia.

Tavares Mourão, I.A., 2005. Portugueses em terras do Dai-Viêt (Cochinchina e Tun Kim): 1615-1660. Instituto Portugês do Oriente, p. 374.

Thera, R.P., 1967. Jinakalamali Prakorn. Translated into Thai by Saeng Monwitoon Mitra Nara Publishing, Bangkok, Thailand, in Thai.
Tsay, J.-D., 2004. Water Vapor Budget of Cold Surge Vortices. MS. Iowa State University, $120 \mathrm{pp}$.

Turpin, F.H., 1771. Histoire civile et naturelle du royaume de Siam. Chez Costard, Paris.

Vickery, M., 1977. Cambodia After Angkor, the Chronicular Evidence for the Fourteenth to Sixteenth Centuries (Ph.D thesis). Yale University, USA.

Vickery, M., 2004b. Cambodia and its Neighbors in the 15th Century. Asia research Institute Working Paper Series No. 27.

Vickery, M., 2011. Champa revised. In: Tran, K.P., Lockhart, B. (Eds.), The Cham of Vietnam. National University of Singapore Press.

Wang, B., 2006. The Asian Monsoon. Praxis Publishing Limited, Chichester, UK, 788 pp.

Wang, B., LinHo, 2002. Rainy season of the asian' Pacific summer monsoon. J. Clim. 15, 386-398.

Wang, S.-Y., Buckley, B.M., Yoon, J.-H., Fosu, B., 2013. Intensification of pre-monsoon tropical cyclones in the Bay of Bengal and its impacts on Myanmar. J. Geophys. Res. 118, 1-12.

Wang, Y.J., Cheng, H., Edwards, R.L., He, Y.Q., Kong, X.G., An, Z.S., Wu, J.Y., Kelly, M.J., Dykoski, C.A., Li, X.D., 2005. The Holocene Asian monsoon: links to solar changes and North Atlantic climate. Science 308, 854-857.

Wongthes, S., 2009. Outline of Thai History, third ed. Knowledge Dissemination fund of Thailand. Bangkok. $250 \mathrm{pp}$.

Wyatt, D.K., Wichienkeeo, A., 1998. The Chiang mai Chronicle. Silkworm Books, Chiang Mai, Thailand, 234 pp.

Yancheva, G., Nowaczyk, N.R., Mingram, J., Dulski, P., Schettler, G., Negendank, J.F.W., Liu, J., Sigman, D.M., Peterson, L.C., Haug, G.H., 2007. Influence of the intertropical convergence zone on the East Asian monsoon. Nature. http:// dx.doi.org/10.1038/nature05431.

Yoon, J.H., Chen, T.C., 2005. Water vapor budget of the Indian monsoon depression. Tellus A 57, 770-782.

Yoon, J.-H., Huang, W.-R., 2012. Indian monsoon depression: climatology and variability. In: Wang, S.-Y., Gillies, R.R. (Eds.), Modern Climatology. ntech.

Zhang, P., Cheng, H., Edwards, R.L., Chen, F., Wang, Y., Yang, X., Liu, J., Tan, M., Wang X. Liu, J. 2008. A test of climate, sun, and culture relationships from an 1810-year Chinese cave record. Science 322, 940-942.

Zhang, R.-H., Levitus, S., 1997. Structure and Cycle of decadal variability of upperocean temperature in the North Pacific. J. Clim. 10, 710-727.

Zhang, Y., Wallace, J.M., Battisti, D.S., 1997. ENSO-like interdecadal variability: 1900-93. J. Clim. 10, 1004-1020.

Zhang, Z., Chan, J.C.L., Ding, Y., 2004. Characteristics, evolution and mechanisms of the summer monsoon onset over Southeast Asia. Int. J. Clim 24, 14611482. 